\title{
A Novel Virus of the Genus Cilevirus Causing Symptoms Similar to Citrus Leprosis
}

\author{
Avijit Roy, Nandlal Choudhary, Leon M. Guillermo, Jonathan Shao, Ananthakrishnan Govindarajulu, Diann Achor, \\ G. Wei, D. D. Picton, L. Levy, M. K. Nakhla, John S. Hartung, and R. H. Brlansky
}

First, second, fifth, sixth, and twelfth authors: University of Florida, IFAS, Plant Pathology Department, Citrus Research and Education Center, 700 Experiment Station Road, Lake Alfred; third author: Centro de Investigación La Libertad, CORPOICA, Villavicencio, Colombia; fourth and eleventh authors: United States Department of Agriculture (USDA)-Agricultural Research Service, MPPL, Beltsville, MD; seventh, eighth, and tenth authors: USDA Animal and Plant Health Inspection Service (APHIS) PPQ-CPHST, Beltsville, $\mathrm{MD}$; and ninth author, USDA-APHIS-PPQ-CPHST, Riverdale, MD.

Accepted for publication 14 November 2012.

\begin{abstract}
Roy, A., Choudhary, N., Guillermo, L. M., Shao, J., Govindarajulu, A., Achor, D., Wei, G., Picton, D. D., Levy, L., Nakhla, M. K., Hartung, J. S., and Brlansky, R. H. 2013. A novel virus of the genus Cilevirus causing symptoms similar to citrus leprosis. Phytopathology 103:488-500.

Citrus leprosis in Colombia was previously shown to be caused by cytoplasmic Citrus leprosis virus (CiLV-C). In 2011, enzyme-linked immunosorbent assay and reverse-transcription polymerase chain reaction (RT-PCR)-based diagnostic methods failed to identify CiLV-C from citrus samples with symptoms similar to citrus leprosis; however, virions similar to CiLV-C were observed in the cytoplasm of the symptomatic leaves by transmission electron microscopy. Furthermore, the causal organism was transmitted by the false spider mite, Brevipalpus phoenicis, to healthy citrus seedlings. A library of small RNAs was constructed from symptomatic leaves and used as the template for Illumina high-throughput parallel sequencing. The complete genome sequence and structure of a new bipartite RNA virus was determined. RNA1 (8,717 nucleotides [nt]) contained two open reading frames (ORFs). ORF1 encoded the replication module, consisting of five domains: namely, methyltransferase
\end{abstract}

ABSTRACT

Citrus leprosis is one of the most economically important viral diseases of Citrus spp. in South and Central America (5). Two types of virions, one in the cytoplasm (Citrus leprosis virus cytoplasmic type [CiLV-C]) and the other in the nucleus (CiLV nuclear type [CiLV-N]) have been reported from citrus leprosis-symptomatic tissues. CiLV-N has been restricted to states of Sao Paulo, Rio Grande do Sul, and Minas Gerais in Brazil and Boquete in Panama (5), whereas CiLV-C has been spreading rapidly in South and Central America. Citrus leprosis was formerly a major problem in Florida but has not been found there since the 1960s (9). Both causal viruses are transmitted by the tenuipalpid false spider mite, Brevipalpus spp. (40,41). Brazilian citrus growers control citrus leprosis by applying acaricides (two to four sprays/season) costing $\approx \$ 80$ million US every year $(5,40)$.

Corresponding author: R. H. Brlansky; E-mail address: rhby@ufl.edu

GenBank accession numbers for the sequences reported in this article are JX000024 (RNA1) and JX000025 (RNA2).

* The $\boldsymbol{e}$-Xtra logo stands for "electronic extra" and indicates that Figures 3 and 4 appear in color online.

http://dx.doi.org/10.1094/PHYTO-07-12-0177-R

(C) 2013 The American Phytopathological Society
(MTR), cysteine protease-like, FtsJ-MTR, helicase (Hel), and RNAdependent RNA polymerase (RdRp); whereas ORF2 encoded the putative coat protein. RNA2 (4,989 nt) contained five ORFs that encode the movement protein (MP) and four hypothetical proteins (p7, p15, p24, and p61). The structure of this virus genome resembled that of CiLV-C except that it contained a long $3^{\prime}$ untranslated terminal region and an extra ORF (p7) in RNA2. Both the RNA1 and RNA2 of the new virus had only 58 and 50\% nucleotide identities, respectively, with known CiLV-C sequences and, thus, it appears to be a novel virus infecting citrus. Phylogenetic analyses of the MTR, Hel, RdRp, and MP domains also indicated that the new virus was closely related to CiLV-C. We suggest that the virus be called Citrus leprosis virus cytoplasmic type 2 (CiLV-C2) and it should be unambiguously classified as a definitive member of the genus Cilevirus. A pair of CiLV-C2 genome-specific RT-PCR primers was designed and validated to detect its presence in citrus leprosis samples collected from the Casanare and Meta states in Colombia.

Additional keywords: citrus virus, deep sequencing, detection, Illumina, mite transmission.

Citrus leprosis affects various Citrus spp. but the degree of symptom severity depends on the citrus variety, with sweet orange (Citrus sinensis L.) being the most susceptible host $(4,5)$. CiLV-C infection causes localized chlorotic lesions, often with necrotic centers. Severe infection in sweet orange can lead to defoliation, fruit drop, reduction of quality and yield, dieback, and, ultimately, tree death within a few years (6). Recently, Hibiscus green spot virus (HGSV) was reported from Hawaii displaying citrus-leprosis-like symptoms on Volkamer lemon (C. volkameriana Tan. and Pasq.) (31).

CiLV-C is the type member of the new genus Celivirus but further taxonomic classifications are undetermined. The short membrane-bound bacilliform virions ( 50 to 60 by 110 to $120 \mathrm{~nm}$ ) are found in the cytoplasm of the infected cells using transmission electron microscopy (TEM) (13). The $\approx 14$-kb bipartite, singlestranded (ss), positive-sense genomic RNA (gRNA) of CiLV-C is composed of RNA1 $(8,729$ to 8,730 nucleotides [nt]) and RNA2 $(4,969$ to $4,975 \mathrm{nt})(28,37)$.

In 2006, CiLV-C was first reported in Colombia from the piedmont area of the eastern plains of Casanare and Meta states, although citrus leprosis symptoms on leaves and fruit of Valencia sweet orange were first observed in Casanare in 2003 and, later, in Meta in 2004 (25). TEM and reverse transcription polymerase chain reaction (RT-PCR) successfully identified CiLV-C from citrus leprosis samples from Yopal and Aguazul in Casanare state and from Cumaral, Guamal, and Villavicencio in Meta state (25). 
In 2008, the non-citrus rutaceous plant Swinglea glutinosa Merr. ('Blanco'), which is often grown as hedgerows in Colombia, was found naturally infected with CiLV-C (23). Confirmation of a symptom-based diagnosis of CiLV-C depends on enzyme-linked immunosorbent assay (ELISA) (10) or RT-PCR (27). In 2011, these tests were applied to confirm CiLV-C associated with citrusleprosis-like symptoms but failed to identify CiLV-C from affected samples even though virions similar to CiLV-C were observed in cytoplasm. Therefore, the pathogen causing citrusleprosis-like symptoms in these samples from Colombia was unknown.

The advent of high-throughput sequencing (HTS) technology and its application allows not only the identification of known pathogens but also the assembly of genome sequences of unknown pathogens associated with diseases $(1,2,21,52)$. Small RNAs (sRNAs) derived from viral genomes accumulate in the virus-infected tissues due to antiviral defense. Assembly of overlapping sRNA sequences was considered for virus identification utilizing HTS (26,38). Both RNA and DNA viruses activate RNA silencing, which is initiated when viral doublestranded (ds)RNA is recognized by Dicer-like (DCL) endoribonucleases (26). Thus, the sRNA deep sequencing (sRDS) is a novel approach that can identify both RNA and DNA viruses $(21,54)$. The sRDS approach was utilized first in plant virology to identify five sweet potato viruses in a single plant (21). A similar approach was applied to identify virus sequences from fruit fly, mosquito, and nematode cells (52). The method has since been used for the discovery of plant viral pathogens associated with diseases in citrus $(29,30)$, vineyards $(12,36,54)$, Dactylis glomerata, the wild cocksfoot grass (35), and sweet potato (18).

The objective of this study was to identify the cause of citrusleprosis-like symptoms found in multiple locations in Colombia where diagnostics for CiLV-C based on results of ELISA and RTPCR assays were negative. We utilized HTS of sRNA to identify and further characterize the unknown virus associated with citrus leprosis-symptomatic plants in Colombia.

\section{MATERIALS AND METHODS}

Plant materials and virus sources. Thirty-two sweet orange samples with severe symptoms of citrus leprosis were collected from locations in Casanare and Meta states, Colombia. Symptomatic and healthy leaf, fruit, and twig samples were shipped to the United States Department of Agriculture-Animal and Plant Health Inspection Service (USDA-APHIS)-PPQ-CPHST, Beltsville, MD for testing under APHIS permits P526P-09-02704 and $\mathrm{P} 526 \mathrm{P}-11-04003$, and further processed in the Bio-containment Level 3 Agriculture (BCL3-Ag) facility. Symptomatic leaf samples were washed with water, and air dried; then, the chlorotic and yellow halo leaf spots (5 to $7 \mathrm{~mm}$ in diameter) were excised using stainless steel razor blades. In all, 8 to 10 lesions (equivalent to $100 \mathrm{mg}$ of tissue) were pooled and stored at $-20^{\circ} \mathrm{C}$ before isolation of total nucleic acids. CiLV-C-infected leaf tissues from Panama (received under permit P526P-11-04003) and healthy sweet orange leaf samples from the greenhouse of Citrus Research and Education Center, Lake Alfred, FL were used throughout the study as positive and negative controls, respectively.

ELISA and RT-PCR. Citrus-leprosis-like symptomatic tissues were excised using stainless steel razor blades and homogenized in extraction buffer at a 1:20 ratio (wt/vol); 1× phosphate-buffered saline (PBS), $\mathrm{pH}$ 7.4. Crude extracts of citrus-leprosis-affected plants were tested with $\mathrm{CiLV}-\mathrm{C}$-specific polyclonal antibody (PAb) CREC-13 using double-antibody sandwich (DAS)-ELISA following the protocol developed by Choudhary et al. (10), with modification $(11,15)$. A 1:1,000 dilution of the primary antibody CREC-13 was used in ELISA to test CiLV-C isolates (antigen dilution 1:20) from Panama (10). Healthy sweet orange leaf tissues and sample extraction buffer (PBS-Tween with $0.2 \%$ poly- vinylpyrrolidone) were used as negative controls. The optical density at $405 \mathrm{~nm}\left(\mathrm{OD}_{405}\right)$ values were recorded after subtracting the average $\mathrm{OD}_{405}$ values of healthy sweet orange leaf tissue and extraction buffer. Citrus-leprosis-affected plants were considered positive if the recorded $\mathrm{OD}_{405}$ values were at least three times greater than the negative control.

Total RNA from healthy citrus leaf tissues as well as from the plant affected with citrus-leprosis-like symptoms in Colombia was extracted using the RNeasy Plant Mini Kit (Qiagen, Valencia, CA) following the manufacturer's protocol. Primer pairs specific to the CiLV-C replicase (RNA1, p285) and movement protein (MP) genes (RNA2, p32) were used to amplify targets from CiLV-C-type isolates following the published RT-PCR protocol (27). In addition, the HGSV RNA1-specific primer pairs (from open reading frame [ORF]1) also were used to detect the presence of HGSV from citrus-leprosis-affected samples following the RTPCR protocol described by Melzer et al. (31).

TEM. Symptomatic chlorotic leaf spots from citrus leprosis and samples of asymptomatic leaf tissues were fixed following the protocol described by Hartung et al. (16). Tissue was fixed for $24 \mathrm{~h}$ at $4^{\circ} \mathrm{C}$ in $3 \%$ glutaraldehyde in $0.066 \mathrm{M}$ phosphate buffer, $\mathrm{pH}$ 6.8. The glutaraldehyde was removed by three washes with phosphate buffer and the samples were then post-fixed in $2 \%$ osmium tetroxide for $4 \mathrm{~h}$. The samples were dehydrated in a graded acetone series and then infiltrated and embedded in Spurr's resin (48). Ultrathin sections were prepared with an LKBHuxley ultramicrotome (LKB Instruments, Ltd., Rockville, MD) and placed on 200-mesh Formvar-coated copper grids. The grids were stained with $2 \%$ aqueous uranyl acetate followed by Reynolds lead citrate (39) and then examined with a Morgagni 268 transmission electron microscope (FEI, The Netherlands).

Mite transmission. The tenuipalpid false spider mite, Brevipalpus phoenicis (Geijskes), is an insect vector of CiLV-C in Colombia and was used for transmission studies (24). B. phoenicis mites were collected from a leprosis-symptom-free citrus grove and nonviruliferous laboratory mite colonies were established from their eggs and maintained on virus-free sweet orange fruit with scab lesions following previously described protocols $(34,41)$. For transmission studies, 80 to 100 nonviruliferous mites were fed on 6 to 8 sweet orange seedlings with leprosis-like symptoms. An acquisition access period (AAP) of $72 \mathrm{~h}$ at $27 \pm$ $1^{\circ} \mathrm{C}$ was used for virus acquisition. After the AAP, 8 to 10 mites per leaf were then placed on each of the 10 virus-free sweet orange seedlings. Transfers were done using a number 01 Sable brush and a stereoscopic microscope. To keep the mites confined, petroleum jelly was applied to the petiole of the inoculated leaves. An inoculation access period (IAP) of $72 \mathrm{~h}$ at $27 \pm 1^{\circ} \mathrm{C}$ with $75 \pm$ $5 \%$ relative humidity was used. After the IAP, all the mites were removed and stored in $70 \%$ ethanol for further analysis.

Construction of sRNA libraries for deep sequencing. Plants with symptoms similar to citrus leprosis but which were negative for CiLV-C by RT-PCR were selected. Total RNA from two composite samples, L147V1 and GD1234, was isolated using RNeasy Plant Mini Kit (Qiagen). From each pooled RNA sample, $50 \mu \mathrm{l}$ was sent for HTS service on the Illumina GA IIX platform (Fasteris SA, Switzerland).

Discovery of a new virus tentatively named CiLV cytoplasmic type 2 from citrus-leprosis-symptomatic plants. Two libraries of fastq reads of 15 to 35 bases containing a potential virus from sRDS were analyzed with a subtractive approach. The citrus genome, known plant virus, and viroid sequences were identified and removed using bowtie, a short-read alignment tool (22). The remaining reads were assembled using the Velvet/Oases suite using various kmers $(47,53)$. The resulting transcripts and contigs were subjected to a blastx program (3) against a nonredundant protein database from the National Center for Biotechnology Information (NCBI) (http://www.ncbi.nlm.nih.gov) using the standard parameters. Novel sequences that matched 
virus sequences with low $e$ values were similar to CiLV-C. The $e$ values obtained from blastx search ranged from e-24 to 1.5 . Protein domains were determined using the "simple modular architecture research tool" (SMART) (46) and the Conserved Domain Database (CDD) programs (http://www.ncbi.nlm.nih.gov/ Structure/cdd/cdd.shtml).

Singleton reads of CiLV cytoplasmic type 2 (CiLV-C2) RNA1 and RNA2 from sRDS data were assembled and several contigs were obtained at different positions of the new virus genome associated with citrus leprosis. Based on a partial CiLV-C2 genome sequence, specific nucleotide regions were selected to design the RT-PCR primers to bridge gaps between contigs for completion and confirmation of the entire genome sequence of CiLV-C2 (RNA1 and RNA2), excluding $5^{\prime}$ and $3^{\prime}$ untranslated regions (UTRs). In all, $\approx 1.3$ - to 1.8 -kb overlapping RT-PCR amplicons with an overlap of 44 to 620 nt were amplified (Table 1) and cloned following a previously described protocol applied for Citrus tristeza virus (CTV) (44). At least three to five clones were bidirectionally sequenced for each overlapping amplicon with an ABI Prism 3100 automatic DNA Sequencer (DNA Sequencing Core Laboratory, Gainesville, FL). Overlapping sequences were aligned using BLAST (bl2seq) and assembled using the ClustalX (50) and GeneDoc version 2.6.002 (33) algorithms to complete the nucleotide sequence of the CiLV-C2 associated with citrus-leprosis-like symptoms.

The 5' and 3' UTRs from RNA1 and RNA2 were obtained by amplifying the terminal mRNA sequences utilizing RNA ligasemediated rapid amplification of cDNA ends (RLM-RACE) (catalog number AM1700; Ambion, Life Technologies, Carlsbad, CA) following the manufacturer's instructions. The CiLV-C2 $5^{\prime}$ and $3^{\prime}$ RACE gene-specific outer and inner reverse primers specific to the RNA1 or RNA2 genomes were designed and utilized (Table 1). Outer and inner $5^{\prime}$ and $3^{\prime}$ RLM-RACE PCR amplicons were cloned and a minimum of five clones for each terminus was sequenced for further analysis.
Preparation of riboprobes and Northern blot hybridization of CiLV-C2 RNAs. Total RNA $(\approx 2.50 \mu \mathrm{g})$ from symptomatic citrus leprosis leaves from Colombia, CiLV-C-positive controls from Panama, and healthy sweet orange leaves were separated by electrophoresis in a formaldehyde-containing $1 \%$ agarose gel and transferred to a positively charged nylon membrane (catalog number 11209299001; Bio-Rad, Hercules, CA). Northern blot hybridizations were performed using a digoxigenin (DIG) Northern starter kit (catalog number 12039672910; Roche, Indianapolis, IN). DIG-labeled specific RNA probes designated as pCiLV-C2-p29 and pCiLV-C2-p24 complementary to the 3'terminal region of RNA1 and RNA2, respectively, were generated according to the in vitro transcription labeling technique using the manufacturer's protocol. The positive-sense DIG-labeled RNA probes were used to probe total RNAs extracted from citrusleprosis-affected tissues and healthy tissue controls for hybridization according to standard methods (45). The hybridized probes were detected with anti-DIG-AP-Fab fragments and were visualized with the chemiluminescence substrate CDP-Star and $\mathrm{X}$-ray film. The 0.5 - to $10-\mathrm{kb}$ RNA ladder $(5 \mu \mathrm{l})$ (catalog number 15623-200; Life Technology) was used as a molecular mass reference.

Phylogenetic analyses. Amino acid sequences of three conserved protein domains (methyltransferase [MTR], helicase [Hel], and RNA-dependent RNA polymerase [RdRp]) encoded on RNA1 and the MP domain of RNA2 were used to compare phylogenetic relationships of the newly discovered virus (CiLVC2) with other selected plant viruses. Phylogenetic analysis was completed using the MEGA5 (49) program, with neighborjoining and bootstrap analysis supported by 1,000 replicates with default parameters. All alignments were performed using the ClustalX algorithm (50). Phylogenetic trees based on MTR, Hel, RdRp, and MP domains from selected viruses were constructed.

Specific detection of the new cytoplasmic virus, CiLV-C2, from citrus-leprosis-affected samples in Colombia. Total RNA

TABLE 1. Oligonucleotide primers used for amplification of the complete RNA1 and RNA2 genomes of Citrus leprosis virus cytoplasmic type 2 from Colombia

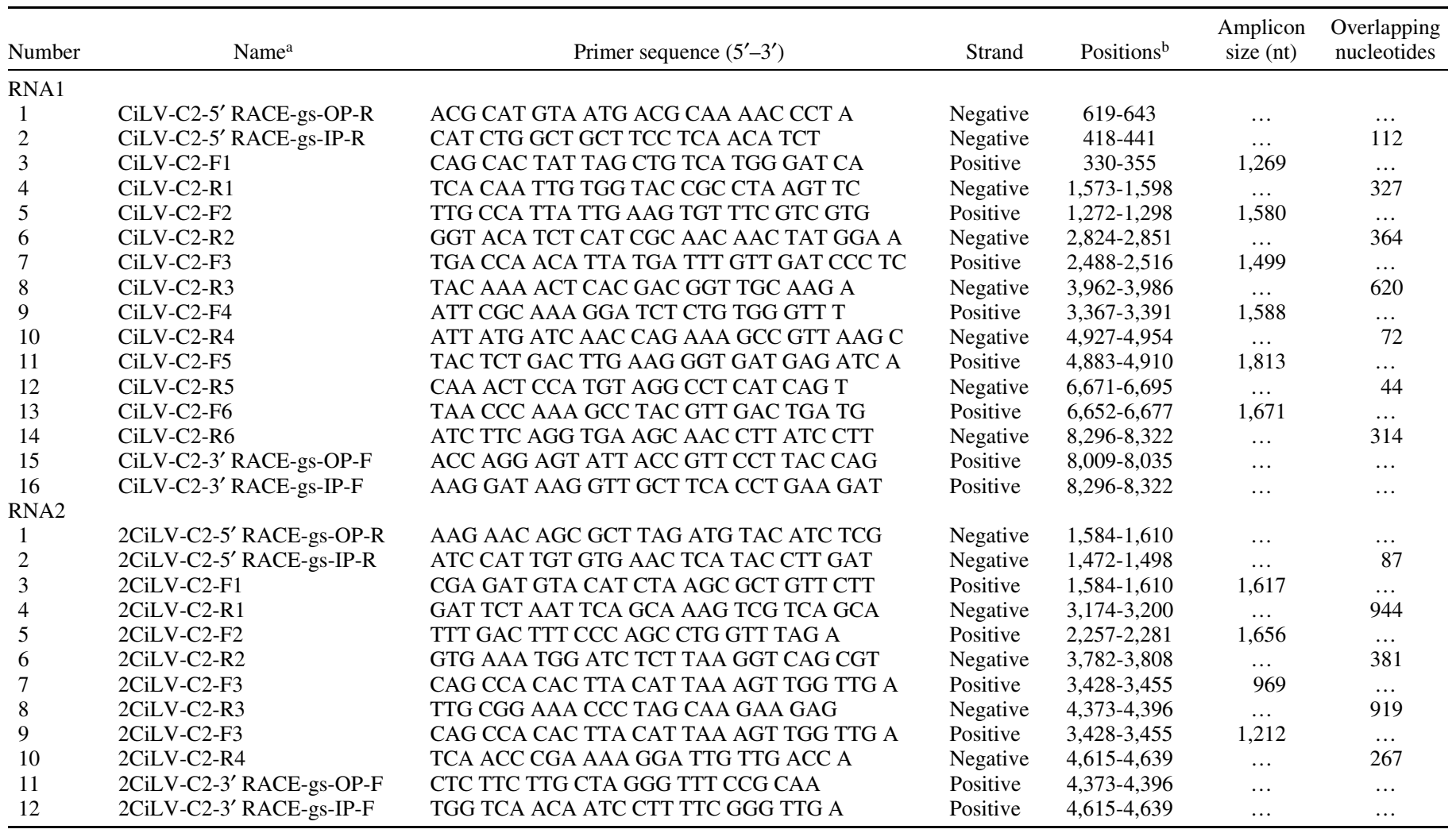

a $\mathrm{RACE}=$ rapid amplification of cDNA ends.

${ }^{\mathrm{b}}$ Nucleotide (nt) positions. 
was extracted from healthy Valencia sweet orange leaves and from leaves with leprosis-like symptoms. In total, 32 leprosis-like samples from four sweet orange cultivars ('Valencia', 'Delta Valencia', 'Rhode Red Valencia', and 'Cara Cara Navel') were extracted. All extractions were completed using the RNeasy Plant Mini Kit (Qiagen) and were analyzed for the presence of CiLV-C by RT-PCR (27). CiLV-C2 putative coat protein gene (CPG) (RNA1-ORF2)-specific positive-sense (CiLV-C2-CPG-F: ${ }^{7699}$ ATG AGT AAC ATT GTG TCG TTT TCG TTG $\mathrm{T}^{7726}$ ) and negativesense primers (CiLV-C2-CPG-R: ${ }^{8493}$ TCA CTC TTC CTG TTC ATC AAC CTG TT ${ }^{8468}$ ) were designed, optimized, and applied for detection of the CiLV-C2 found in Colombia following the RTPCR protocol described earlier (44). The nucleotide positions are based on the RNA1 genome sequences of the isolate L147V1 (accession number JX000024). PCR products were cloned, sequenced, and compared with existing CiLV-C sequences.

\section{RESULTS}

Citrus-leprosis-like symptoms in Colombia. Symptomatic sweet orange materials for this research work were obtained from Colombia and showed severe disease symptoms like those reported for citrus leprosis. These samples had symptoms of chlorotic leaf spots and yellow halos (Fig. 1A). In advanced stages of infection, the spots coalesced into large areas of chlorosis and the yellow tissue often turned brown (Fig. 1B). Brown ring spots with a central depression were a common symptom on fruit (Fig. 1C). Similar raised brown rings also were observed in twigs or branches (Fig. 1D). In general, the symptoms were similar, if not identical, to those previously reported for CiLV-C in Colombia (25). Severe infections in sweet orange often lead to defoliation and fruit drop, which directly reduce production within a few years.

CiLV-C and HGSV are undetectable in Colombian citrusleprosis-affected plant tissues. Tissues from different sweet orange trees that displayed citrus-leprosis-like symptoms were tested utilizing ELISA (10) and RT-PCR (27) developed for CiLV$\mathrm{C}$ detection. In DAS-ELISA tests, the average calculated absorbance $\left(\mathrm{OD}_{405}\right)$ value of samples with citrus-leprosis-like symptoms was $0.090 \pm 0.002$, compared with the healthy sample average value of $0.109 \pm 0.001$. Known isolates of CiLV-C from Panama had $\mathrm{OD}_{405}$ values measured between $0.439 \pm 0.008$ and $0.684 \pm 0.010$.

In addition, a previously developed RT-PCR assay was utilized (27). No amplicons typical of CiLV-C were produced. The RTPCR assay successfully detected the known CiLV-C isolate from Panama and did not produce any amplicons from healthy sweet orange. We concluded that the Colombian citrus leprosis samples did not contain CiLV-C. Furthermore, HGSV-specific primers (31) were utilized to determine whether citrus-leprosis-like symp-
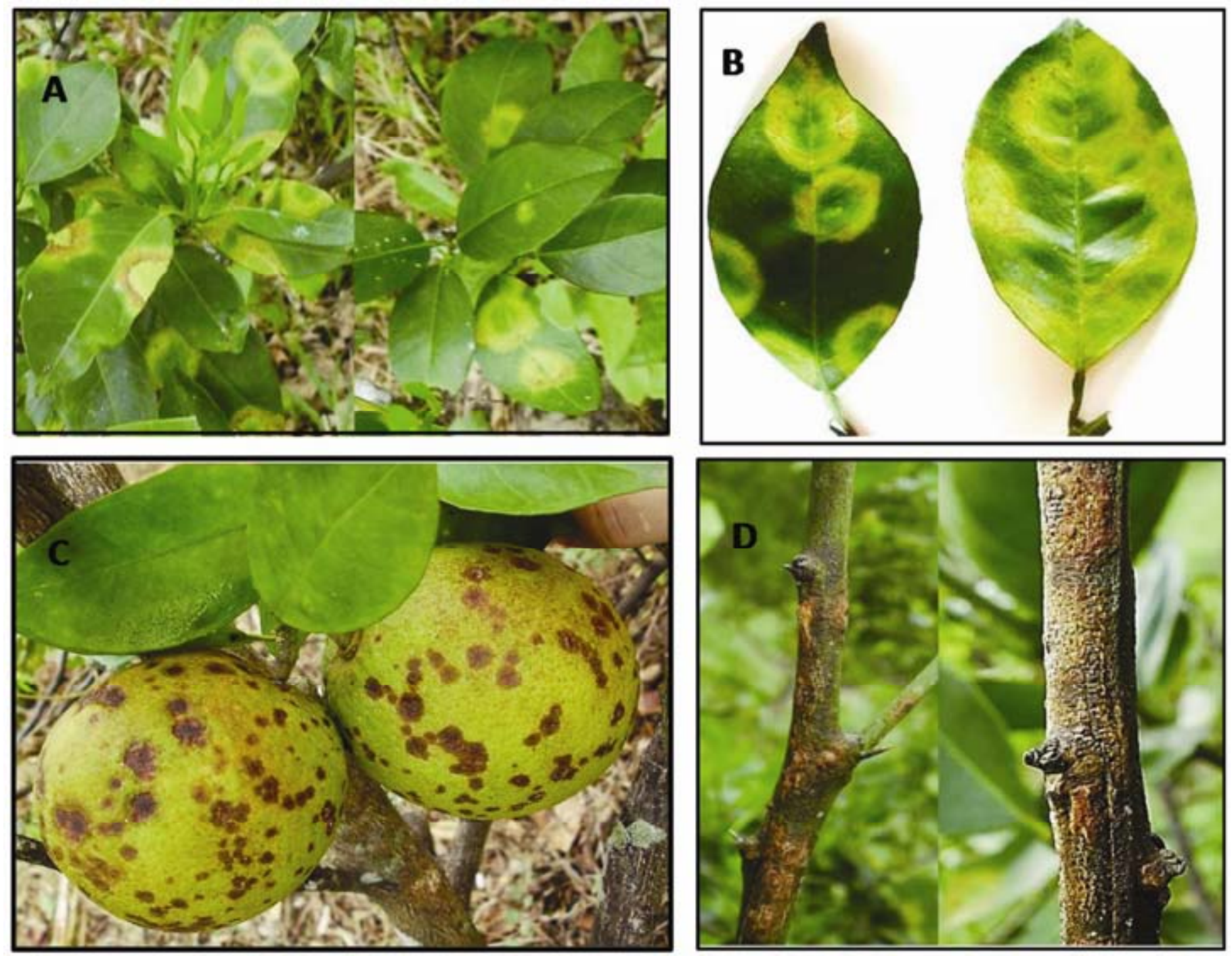

Fig. 1. Citrus-leprosis-affected Valencia sweet orange plant showing typical leprosis symptoms in citrus $\mathbf{A}$ and $\mathbf{B}$, leaves; $\mathbf{C}$, fruit; and $\mathbf{D}$, twigs infected with Citrus leprosis virus cytoplasmic type 2 (CiLV-C2). 
toms were caused by HGSV but no HGSV-specific amplicon was produced.

TEM. TEM was carried out to search for virions in the citrusleprosis-like symptomatic leaf samples. Asymptomatic leaf sections of Valencia sweet orange were also examined for comparisons. Short bacilliform virions (40 to 50 by 100 to $110 \mathrm{~nm}$ ) characteristic of CiLV-C infections were observed within the endoplasmic reticulum in the cytoplasm of the symptomatic leaf samples and compared with CiLV-C from Brazil and Colombia (Fig. 2A to $\mathrm{C}$ ). No particles were observed in the nuclei of the affected samples or in healthy plants (data not shown).

Mite transmission. Citrus-leprosis-like symptoms in the greenhouse-grown Valencia sweet orange plants were characterized by the appearance of small, circular chlorotic leaf spots 25 days after viruliferous $B$. phoenicis inoculation (Fig. 3A). The chlorotic spots increased in size over time and, after 120 days, the spots began to coalesce into larger chlorotic areas (Fig. 3B). Ten plants inoculated with $B$. phoenicis produced citrus-leprosis-like symptoms. In ELISA tests with CiLV-C-specific CREC-13 PAb, the average calculated absorbance $\left(\mathrm{OD}_{405}\right)$ values of $\mathrm{B}$. phoenicisinoculated symptomatic samples were $0.090 \pm 0.002$ and were similar to values obtained for healthy samples $(0.109 \pm 0.001)$. Therefore, the mite transmission samples were considered as negative for CiLV-C infection. The CiLV-C RT-PCR assay also did not produce any amplicon from the B. phoenicis-inoculated sweet orange leaves.

Identification of a new virus in the Colombian citrus leprosis samples using deep sequencing. The genome of a new citrus virus (referred to as CiLV-C2) was identified by HTS of sRNAs from the sweet orange plants showing similar symptoms of citrus leprosis tested negative for CiLV-C infection. Two enriched sRNA libraries, GUB1 from sample L147V1 and GUB2 from sample GD1234, were generated from the total RNA of citrus-leprosis-like symptomatic leaves. The GUB1 and GUB2
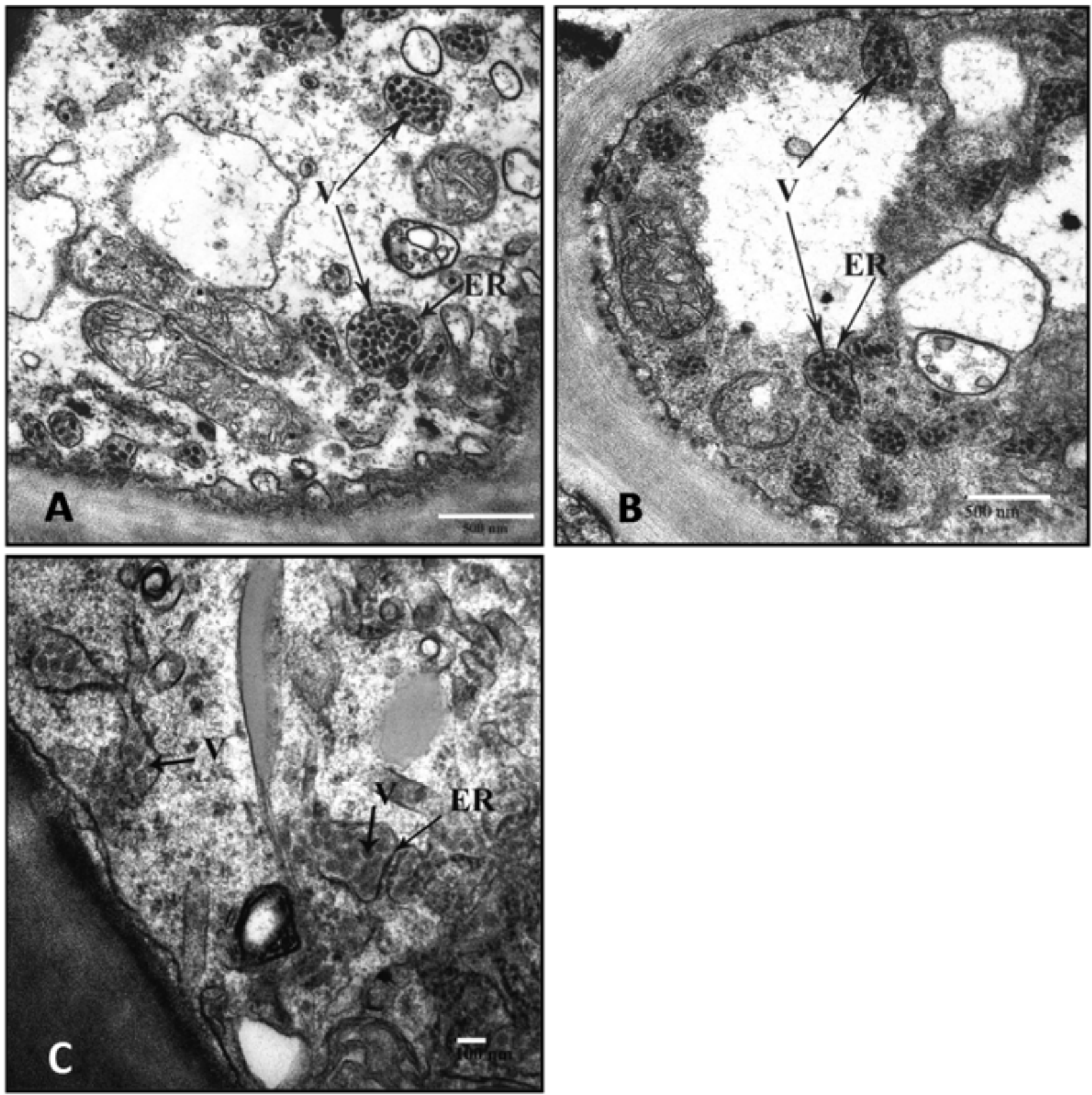

Fig. 2. Transmission electron micrographs of Citrus leprosis virus cytoplasmic type (CiLV-C) from A, Brazil and $\mathbf{B}$, Colombia and compared with $\mathbf{C}$, type 2 (CiLV-C2) from Colombia. Sections were prepared from typical lesions of citrus-leprosis-affected Valencia sweet orange leaves tissues. All virions (V) in the endoplasmic reticulam (ER) of the cytoplasm were of similar size and shape. 
sRNA deep-sequence libraries had 20,935,577 and 16,122,595 single-end raw reads, respectively. Reads were 15 to $35 \mathrm{nt}$ in length. In the GUB1 and GUB2 libraries, reads were mapped to genome sequences of citrus, various genotypes of CTV, and small sequence fragments of other plant viruses. Some reads obtained in the GUB2 library were also mapped to the Citrus exocortis viroid $(\mathrm{CEVd})$ and Citrus dwarfing viroid $(\mathrm{CDVd})$. After subtracting the sequences of the citrus genome, CTV, and citrus viroids, the remaining sequence pools were used to assemble contigs by tiling using two small sequence assembly software programs. The total number of virus contigs was reduced from 231 to 46 for GUB-1 and from 185 to 27 for GUB-2 after subtracting the contigs of CTV and citrus viroids (Table 2). These contigs partially matched the CiLV-C genome in the NCBI nonredundant protein database. From the 46 and 27 contigs assembled from the GUB-1 and GUB-2 libraries, 24 and 9 contigs of 101 to 807 and 102 to 637 $\mathrm{nt}$, respectively, were retained for further analysis because they had the most significant expect (e) values. Overall, 304,846 and 153,295 reads to RNA1 and 328,168 and 240,233 reads to RNA2 were assembled that mapped to the CiLV-C2 genomes from the GUB-1 and GUB-2 libraries, respectively. The majority of reads that mapped to the new leprosis virus had a read length of 21 to 22 bases. Thus, only 2.44 to $3.02 \%$ of the total reads were mapped to the CiLV-C2 sequences. Of the 73 contigs assembled from the GUB-1 and GUB-2 libraries, 23 RNA1contigs (17 encoding p285 and 6 encoding p29) and 10 RNA2 contigs (4 encoding p61, 5 encoding p32 and 1 encoding p24) had 38 to 91 and 32 to $74 \%$ nucleotide-translated protein sequence identity with CiLV-CRNA1 and -RNA2, respectively.

After eliminating the overlapping sequences, the sequences provided coverage of $\approx 33 \%$ (RNA1) and $\approx 55 \%$ (RNA2) of the probable length of the CiLV-C2. These numbers were generated after the complete sequencing of the CiLV-C2 genome. Contigs were aligned with most of the ORFs from the published CiLV-C genome but no contig or singleton reads matched the CiLV-C RNA2-ORF1 sequence that encodes the putative protein $\mathrm{p} 15$. Primers were designed to anneal and bridge the gaps in the sequence, and the expected amplicons were obtained using RTPCR (Table 1). Clones corresponding to the overlapping region were sequenced and aligned to get the complete nucleotide sequences, excluding UTRs. Sanger and deep-sequence data of the CiLV-C2 shared 99\% sequence identity. Neither 5' nor 3' UTR sequences were found by deep sequencing. In total, 316 and 1,350 nt were obtained using 5' UTR RACE whereas 216 and $288 \mathrm{nt}$ were obtained by $3^{\prime}$ UTR RACE for RNA1 and RNA2, respectively, to complete the viral genome.

Complete genome analysis of the CiLV-C2 and comparisons with CiLV-C. The complete genome of CiLV-C2 was 13,706 nt in length. The genome was composed of RNA1 and RNA2 of 8,717 and 4,989 nt, respectively. Both RNAs also had 3 'terminal poly(A) tails. The structure of the CiLV-C2 genome closely resembles the genome organization of CiLV-C. RNA1 of CiLV-C2 is organized into two ORFs, one of them in frame +1 and the other in frame +2 , whereas RNA2 contained five ORFs, one of them in frame +1 and two each in frame +2 and frame +3 .

ORF1 of CiLV-C2 RNA1 started at nucleotide position 119 and terminated at nucleotide position 7633. As observed with Cilevirus type member $\mathrm{CiLV}-\mathrm{C}$, the $\mathrm{CiLV}-\mathrm{C} 2$ genome also encoded a large polyprotein (p285) with five domains. The first and third domains, namely MTR (nucleotides 503 to 1486, 328 amino acids [aa]) (Pfam accession PF01660) and rRNA FtsJ-MTR (nucleotides 2975 to 3256,94 aa) are involved in mRNA capping in
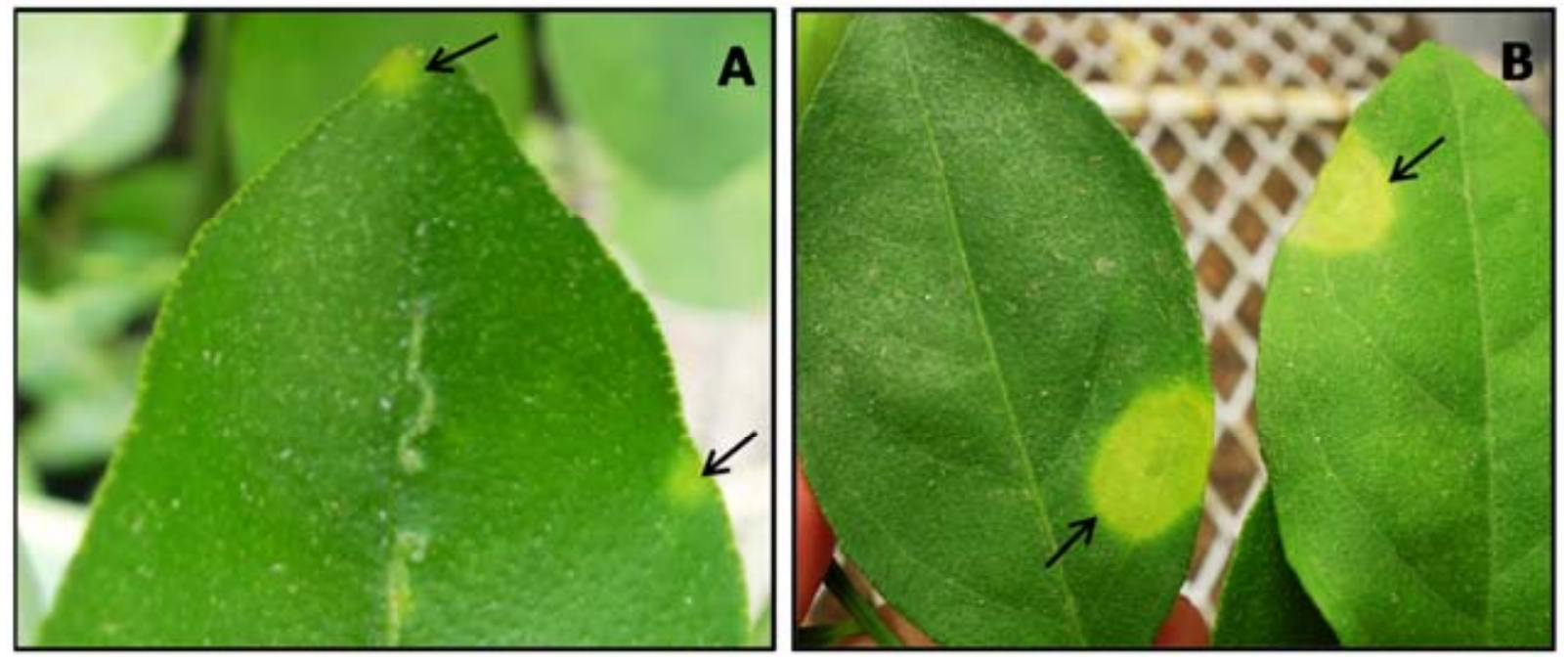

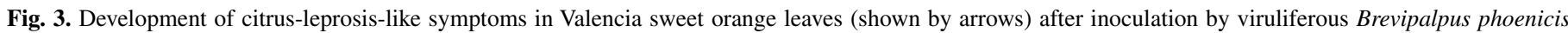

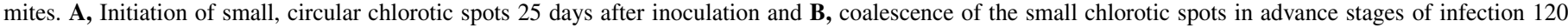
days after inoculation.

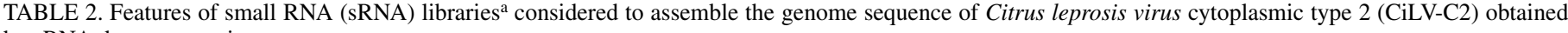
by sRNA deep sequencing

\begin{tabular}{|c|c|c|}
\hline Features of sRNA libraries & Library GUB1 & Library GUB2 \\
\hline Single-end raw reads & $20,935,577$ & $16,122,595$ \\
\hline Reads that map to the citrus genome & $12,512,869$ & $10,170,825$ \\
\hline Reads that map to other plant viruses and viroids & $4,366,936$ & $2,833,216$ \\
\hline Reads that map to Citrus tristeza virus and citrus viroids genome sequences & $4,055,772$ & $3,118,554$ \\
\hline Reads actually aligned with CiLV-C2 & 633,014 & 393,528 \\
\hline Contigs for CiLV-C2 and other citrus virus and viroid related contigs & 231 & 185 \\
\hline Contigs- for CiLV-C2 / -with significant expect values & $46 / 24$ & $27 / 9$ \\
\hline Average length of CiLV-C2 contigs (nt) & 192 & 197 \\
\hline Maximum length of CiLV-C2 contig (nt) & 807 & 637 \\
\hline
\end{tabular}

a Contigs of CiLV-C2 were selected based on CiLV cytoplasmic (CiLV-C) genome. $n t=$ nucleotides. 
CiLV-C and other positive-sense virus genera. The second domain of p285 is similar to cysteine protease (C-Pro) (nucleotides 2174 to 2500,109 aa), as previously reported for CiLV-C (27). The fourth and fifth domains of ORF1-RNA1 are the viral Hel (nucleotides 4757 to 5620, 288 aa) (Pfam accession PF01443) and an RdRp (nucleotides 6257 to 7576, 440 aa) (Pfam accession PF00978), members of the Hel (superfamily 1) and RdRp (superfamily RdRp_2), respectively, and play multiple roles at various stages of virus replication (17). ORF1 of CiLV-C2 had maximum nucleotide and amino acid identities with ORF1 of CiLV-C isolates of only $\approx 60 \%$ (Table 3 ). The conserved domains (MTR,
C-Pro, FtsJ-MTR, Hel, and RdRp) had amino acid sequence identities of $73,68,55,61$, and 75 to $77 \%$, respectively, with the CiLV-C sequences from Brazil and Panama. ORF2 of RNA1 (+1 frame) encodes a putative CP of 264 aa (p29), 1 aa longer than the corresponding protein from CiLV-C (Fig. 4). The putative CPG of CiLV-C2 had only 47 to $48 \%$ nucleotide and $33 \%$ amino acid sequence identity with CPGs of CiLV-C isolates.

Excluding the poly(A) tail, RNA2 of CiLV-C2 was 4,989 nt long. Five ORFs were identified that potentially encoded five proteins with molecular masses of $15,7,61,32$, and $24 \mathrm{kDa}$, respectively (Fig. 4; Table 3). The predicted molecular mass of

TABLE 3. Characteristics of the open reading frames (ORFs) and untranslated regions (UTRs) of RNA1 and RNA2 of Citrus leprosis virus cytoplasmic type 2 (CiLV-C2) and Citrus leprosis virus cytoplasmic (CiLV-C) isolates

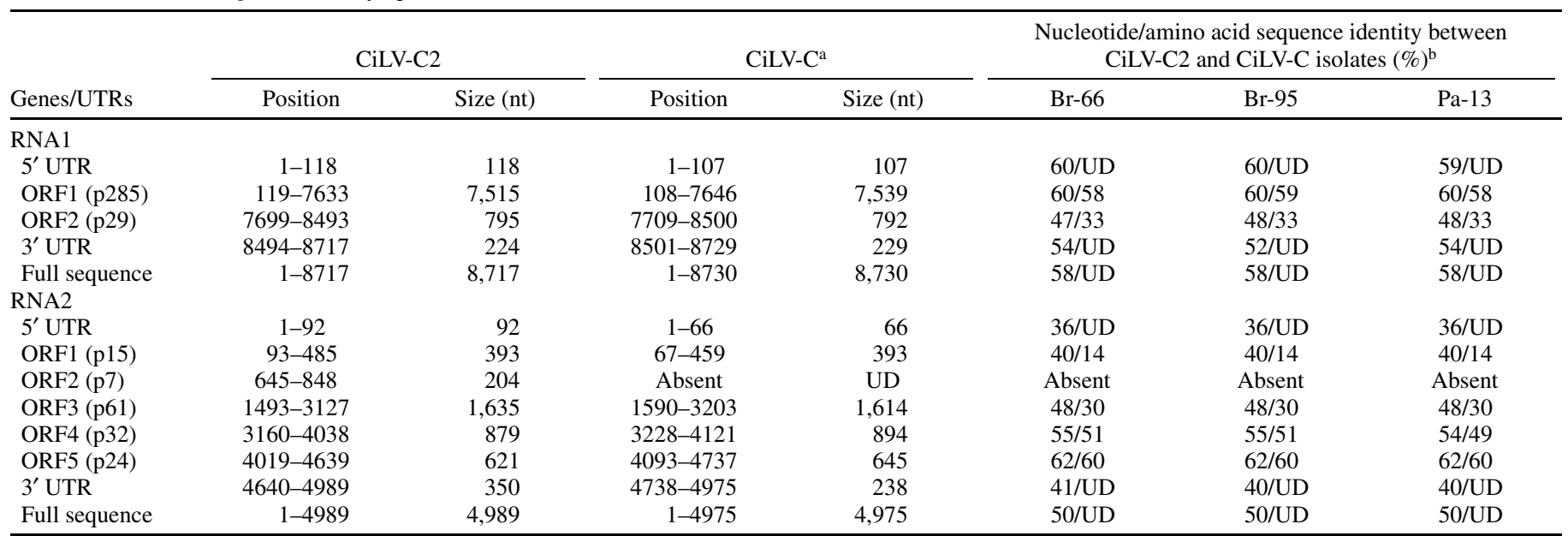

a Nucleotide positions (Position) are based on GenBank accession numbers DQ157466 for RNA1 and DQ157465 for RNA2. Size: nt = nucleotides.

${ }^{\mathrm{b}}$ GenBank accessions are listed after country name: Br-66 = Brazil DQ157465-66, Br-95 = Brazil DQ352194-95, and Pa-13 = Panama DQ388512-13; UD indicates undetermined.

CILV-C2-RNA1 $8717 \mathrm{nt}$
7515 nt

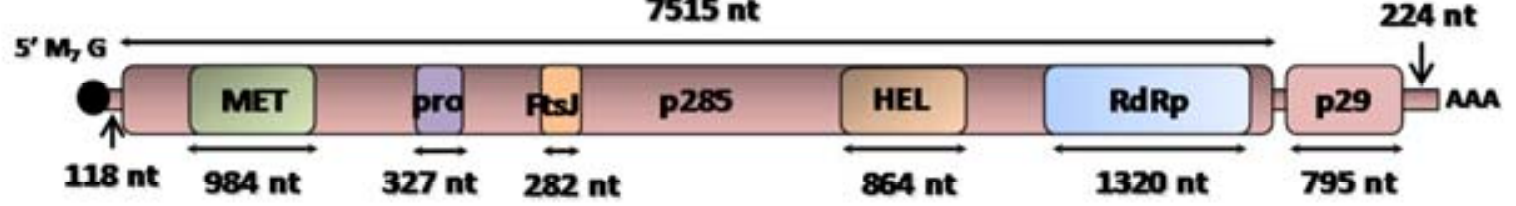

\section{DQ157466/ CiLV-C-RNA1 $8730 \mathrm{nt}$}
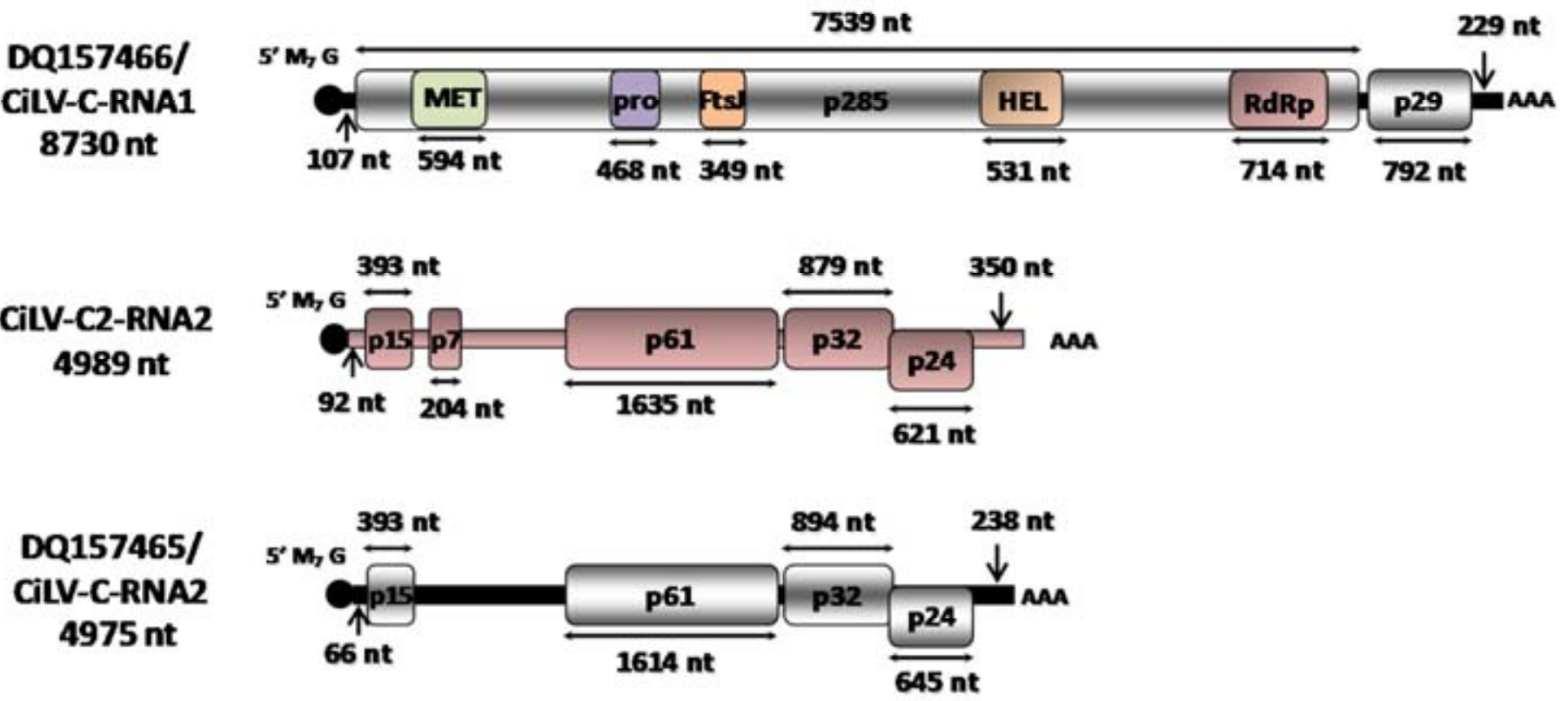

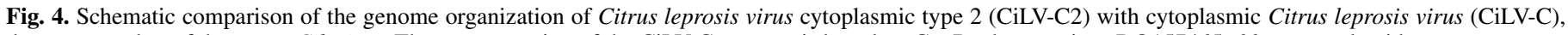
the type member of the genus Cilevirus. The representation of the CiLV-C genome is based on GenBank accessions DQ157465-66; nt = nucleotides. 
proteins from $\mathrm{CiLV}-\mathrm{C} 2$ was similar to the predicted protein masses for CiLV-C. RNA2 of CiLV-C2 also contains sequences of a small hypothetical protein (p7) not found in RNA2 of CiLV-C. Translation of p7 (ORF2-RNA2) originated at nucleotide 645 and contained a putative trans-membrane domain at nucleotide positions 762 to 830 . The genome of CiLV-C did not contain an ORF corresponding to this protein. Translation of ORF2 of RNA2 of CiLV-C started at nucleotide 1,590 after a long (943 nt) intervening UTR. The transcript of 1,614 nt encoded a large hypothetical protein (p61) of RNA2. After an intervening UTR of 643 $\mathrm{nt}$, translation of ORF3 of CiLV-C2 originated at nucleotide 1,493 and also encoded a $61-\mathrm{kDa}$ protein (Table 3). A signal peptide cleavage site was found in the ORF3 amino acid sequence at nucleotides 1493 to 1546 . In addition, a putative trans-membrane domain also was identified at nucleotides 2903 to 2971 . The total length of ORF4 is $879 \mathrm{nt}$ compared with the 840 or $895 \mathrm{nt}$ found in CiLV-C isolates from Panama and Brazil, respectively (Table 3). ORF4 is the only ORF in RNA2 that has a conserved MP domain similar to the 3A/RNA2 superfamily of MPs of various positive-sense ssRNA viruses. ORF5 of RNA2 of CiLV-C2 contained $621 \mathrm{nt}$ and encoded a $24-\mathrm{kDa}(\mathrm{p} 24)$ protein transcribed in a different frame $(+2)$ than ORF1, $-2(+3)$, and $-4(+1)$. ORF5 contained four putative trans-membrane domains at nucleotide positions 4148 to 4201,4259 to 4327,4346 to 4405 , and 4463 to 4522. ORF1, $-3,-4$, and -5 of RNA2 had maximum amino acid sequence identities of $14,30,49$ to 51 , and $60 \%$, respectively, with three other completed CiLV-C sequences (Table 3 ).

Methylated cap-like structures found in the gRNAs of CiLV-C were also observed in the $5^{\prime}$ UTR of both of the CiLV-C2 RNAs. Both CiLV-C2 $5^{\prime}$ UTRs were longer than those of the CiLV-C isolates (Table 3; Fig. 4). Sequence alignment of the $5^{\prime}$ UTRs of RNA1 and RNA2 did not reveal any conserved sequences of more than 4 nt. Nucleotide sequences were more similar in the 3' UTRs between RNA1 and RNA2. Excluding the poly(A) tail, the 3' UTRs of RNA1 and RNA2 were 224 and 350 nt long. The sequence alignment of the $3^{\prime}$ UTRs of the CiLV-C2 RNA1 began at the 1st nucleotide, which corresponds to the 121st nt of RNA2, and showed a very high (75\%) nucleotide identity (data not shown). This is much higher than the overall nucleotide identity of only 52 to 54 and 40 to $41 \%$ observed between CiLV-C and CiLV-C2 RNA1 and RNA2, respectively (Table 3). The 3' UTR nucleotide sequence identity of CiLV-C2 RNA1 and RNA2 increased from 75 to $86.5 \%$ when only the last $126 \mathrm{nt}$ were aligned. A similar pattern of conserved nucleotide sequence identity was also observed between CiLV-C RNA1 and RNA2 (37).

Northern blot hybridization. Northern blot analyses were performed on total RNA to confirm the length and the number of subgenomic RNA (sgRNA) from citrus-leprosis-affected plants in Colombia. DIG-labeled positive-stranded RNA-specific probes of pCiLV-C2-p29 (nucleotides 7699 to 8493) and pCiLV-C2-p24 (nucleotides 4180 to 4716 ) complementary to $3^{\prime}$-terminal regions of the RNA1 and RNA2, respectively, were used for hybridization. The pCiLV-C2-p29-specific probe hybridized with a gRNA1 molecule with an estimated size of $\approx 9 \mathrm{~kb}$. In addition, the same probe also hybridized with an $\operatorname{sgRNA} 1$ of $\approx 1.0 \mathrm{~kb}$, corresponding to a transcript that may serve as a template for the expression of p29 (Fig. 5). Furthermore, a 3' end-labeled RNA2specific riboprobe documented two sgRNAs with estimated sizes of $\approx 3.1$ and $\approx 1.0 \mathrm{~kb}$ along with the full-size gRNA2 of $\approx 5.0 \mathrm{~kb}$ (Fig. 5). No hybridization signals were observed corresponding to the genomic and sgRNAs of CiLV-C. RNA from healthy citrus also did not hybridize with CiLV-C2-specific riboprobes.

Phylogenetic analyses. Four phylogenetic trees were constructed using the amino acid sequences of the three conserved domains (MTR, Hel, and RdRp) of p285 in RNA1 and the MP of RNA2. In all, 20 to 26 members of six to eight closely related virus genera belonging to Bromo-, Cile-, Clostero-, Cucumo-, Furo-, Higre-, Hordei-, Ilar-, Pomo-, Tobamo-, and Tobravirus were included in the phylogenetic analysis of p285. The MTR and Hel domains of CiLV-C2 had 77 and $62 \%$ amino acid sequence identity, respectively, with the MTR and Hel domains of Cilevirus (CiLV-C), followed by a 36 to $40 \%$ amino acid sequence identity with the HGSV. Thus, CiLV-C2 clustered with CiLV-C in the dendrogram, consistent with it being a second member of the genus Cilevirus (Fig. 6A and B). The RdRp domain of Ligustrum ringspot virus (LigRSV) (ADM47770), another Brevipalpus miteassociated virus, showed the greatest (85\%) amino acid sequence identity whereas the RdRp domain of CiLV-C had a 75 to $77 \%$ sequence identity with the RdRp domain of CiLV-C2. Phylogenetic analysis using deduced protein sequences of the RdRp domain confirmed the relatedness of CiLV-C2 to the genus Cilevirus and LigRSV mite-transmitted viruses (Fig. 6C).

The MP of CiLV-C2 shared a $73 \%$ amino acid sequence identity and nearest phylogenetic relationship with the Passion fruit green spot virus (PFGSV) (ADY38390), which is also transmitted by Brevipalpus mites. Other mite-transmitted viruses such as CiLV-C and LigRSV (ADM47769) shared the same clade in the dendrogram but had only 54 to 55 and $39 \%$ amino acid identity, respectively, with CiLV-C2 (Fig. 6D). Partial amino acid sequences of the MP domain of the above-mentioned miteassociated viruses were aligned and conserved amino acid se-

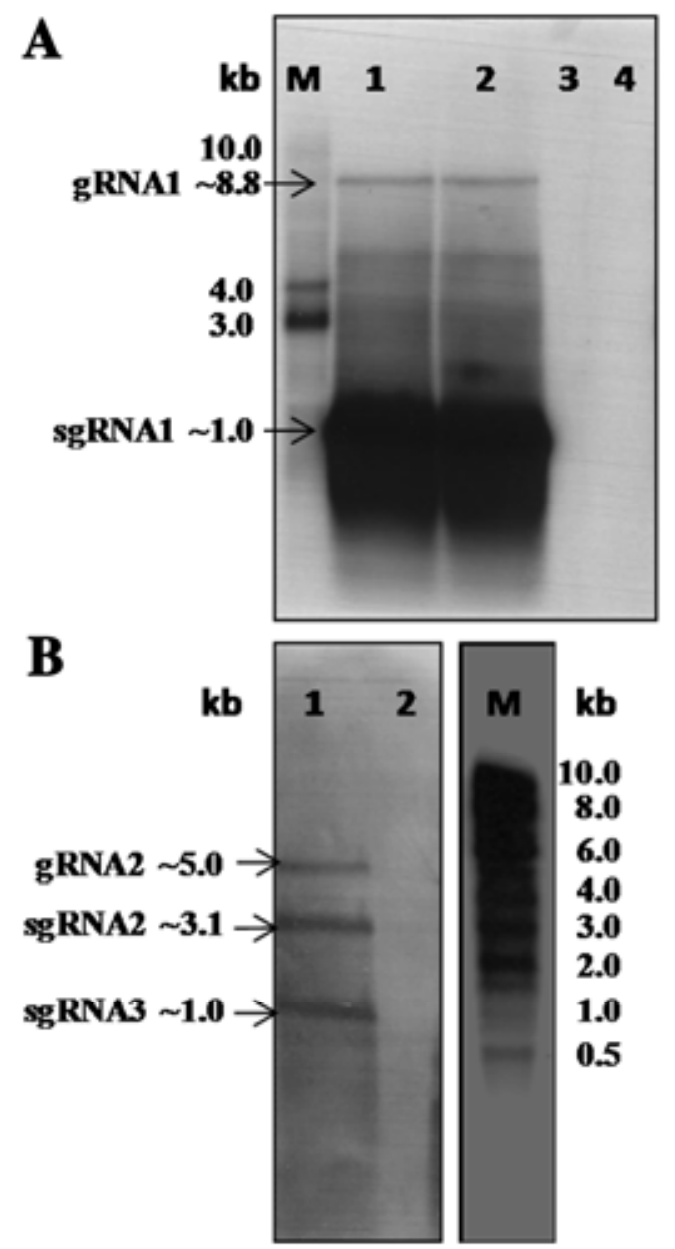

Fig. 5. Northern blots hybridization signals of Citrus leprosis virus cytoplasmic type 2 (CiLV-C2) obtained using specific probes for CiLV-C2-RNA1 and -RNA 2. A, Positive-sense probes pCiLV-C2-p29 for RNA1 were prepared from open reading frame (ORF) 2 that encodes the putative coat protein gene (nucleotides 7699 to 8493) (lanes 1 and 2) and B, pCiLV-C2-p24 that encodes for RNA2 prepared from 3' terminal of ORF p24 (nucleotides 4180 to 4716) (lane 1). M: 0.5- to 10-kb RNA ladder (Life Technologies, Carlsbad, CA). Healthy citrus leaves (lane A3) and CiLV-C (lanes A4 and B2) were used as negative controls. Both the probes gave no signal with total RNA from healthy and CiLV cytoplasmic type samples. 

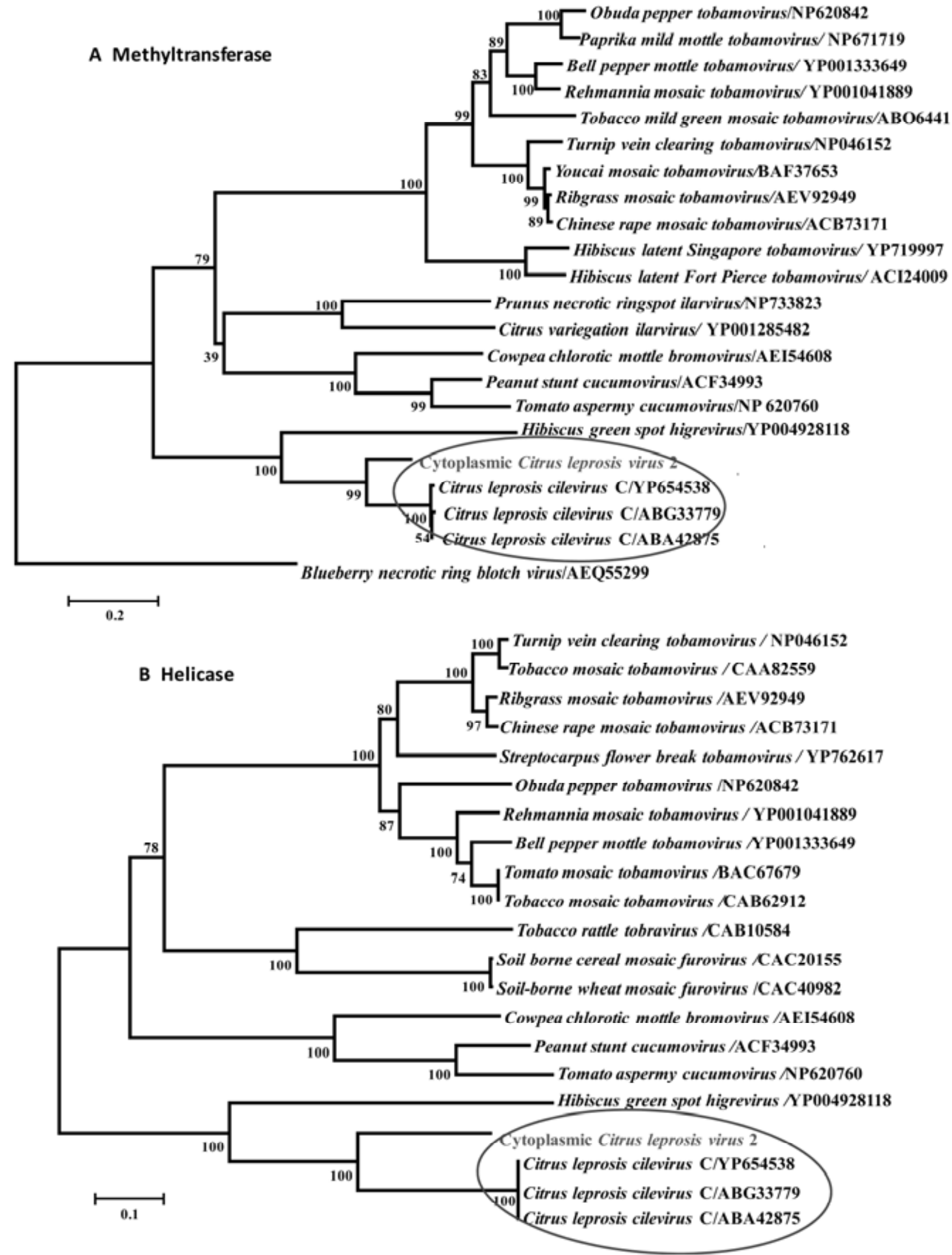

(Continued on next page)

Fig. 6. Phylogenetic relationships among Citrus leprosis virus cytoplasmic type 2 (CiLV-C2) and other related virus genera based on the domains A, methyltransferase; B, helicase; C, RNA-dependent RNA polymerase from RNA1, and D, conserved movement protein from RNA2. All of the virus names and their genera are shown in italics following their GenBank accession numbers (A to D) and the vector associated with virus transmission (D only). The tree was constructed using the MEGA5 program and the neighbor-joining method. Phylogenetic groups were supported by 1,000 bootstrap replicates. Branch lengths are proportional to the genetic distances. CiLV-C2 is circled with the other members of the genus Cilevirus. 


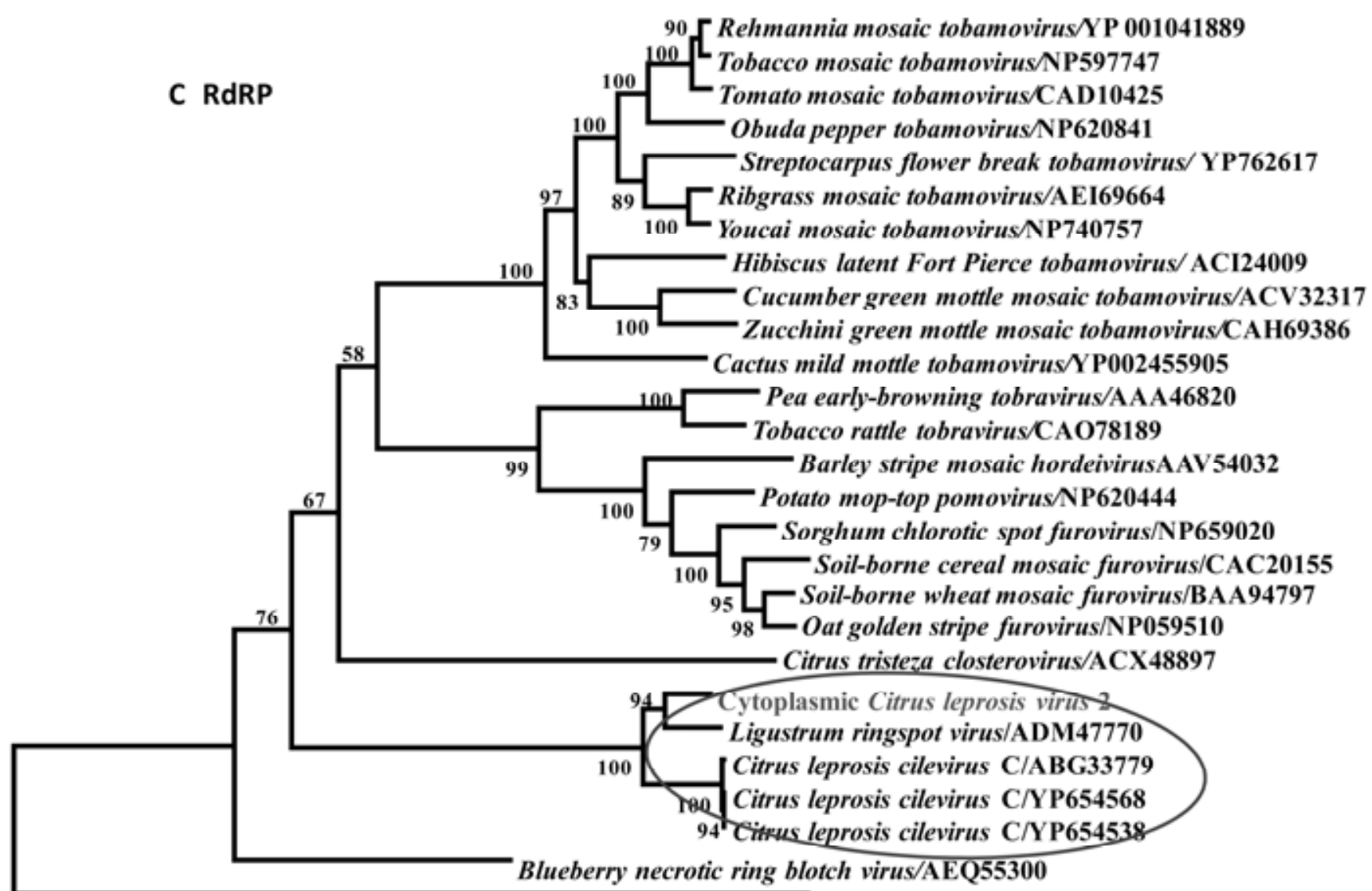

0.2

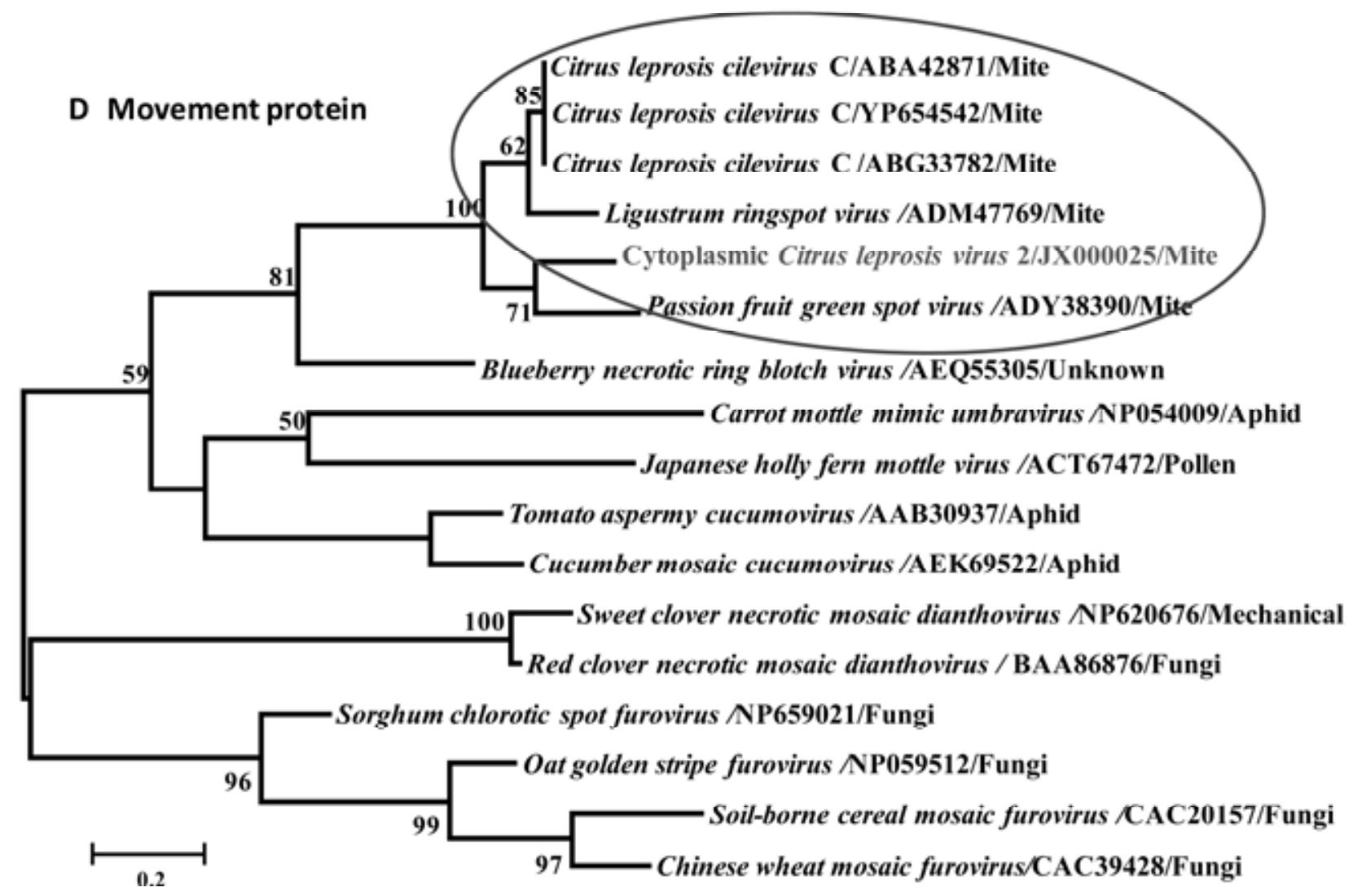

Fig. 6. (Continued from previous page) 
quences at positions 161 to 165 (HRRLG) and 191 to 196 (LWREAF) of CiLV-C2 (accession number JX000025) were detected (Fig. 7).

Detection of CiLV-C2 from Colombian citrus-leprosisaffected samples. Thirty-two citrus plants were tested to determine whether CiLV-C2 was consistently associated with citrusleprosis-like symptoms in Colombia. Samples from Mandarin orange (C. reticulata, Blanco) and four commercial cultivars of sweet orange were collected from commercial citrus groves in the states of Meta and Casanare. CiLV-C- and HGSV-specific primer pairs were used to test citrus-leprosis-affected leaf, fruit, and twig samples by RT-PCR $(27,31)$. No amplicons typical for CiLV-C or HGSV were produced by RT-PCR from any of the samples. The newly developed primer set CiLV-C2-CPG-F and CiLV-C2-CPGR successfully amplified the CPG (795 bp) amplicon from RNA of 32 Colombian citrus leprosis samples and $10 \mathrm{~B}$. phoenicistransmitted Valencia sweet orange seedlings but not from RNA prepared from a reference CiLV-C or healthy sweet orange leaf samples (Fig. 8). Sequencing of the 795-bp RT-PCR amplicon showed 98 to $99 \%$ nucleotide sequence identity with the reference sequence L147V1 (JX000024) and other positive samples of CiLV-C2 from Colombia.

\section{DISCUSSION}

In this study, a novel citrus virus, CiLV-C2, associated with citrus-leprosis-like symptoms in Colombia was characterized utilizing sRDS and a newly developed RT-PCR assay based on the CPG of CiLV-C2 and applied to distinguish CiLV-C2 from CiLV-C.

Leprosis-affected samples from Casanare and Meta states in Colombia were tested for CiLV-C and HGSV using RT-PCR and all samples were negative. In addition, negative DAS-ELISA results were also obtained for CiLV-C. However, TEM results confirmed the presence of CiLV-C2 virions in the cytoplasm but not in the nuclei of the infected tissues. The CiLV-like virion size was similar to that found with CiLV-C and their location in the cytoplasm also ruled out the possibility of CiLV-N and HGSV infections (Fig. 2). Therefore an attempt to identify a new virus present in these symptomatic samples was done using sRDS, and a new bipartite, positive-sense ssRNA virus (CiLV-C2) was discovered. The results suggest that only CiLV-C2 was associated with the Colombian citrus-leprosis-symptomatic tested samples from the states of Meta and Casanare and that the symptoms of CiLV-C2 were similar to those of CiLV-C. CiLV-C2 was detected from citrus-leprosis-affected Mandarin and cultivars of sweet orange previously identified as susceptible hosts for CiLV-C (40). CiLV-C2 was transmitted by the tenuipalpid false spider mite, B. phoenicis, from CiLV-C2-infected citrus to the healthy Valencia sweet orange seedlings and reproduced the disease symptoms of CiLV-C2. The newly developed RT-PCR assay successfully identified CiLV-C2 from sweet orange leaves inoculated with B. phoenicis. CiLV-C, HGSV, LigRSV, and PFGSV are related to CiLV-C2 and are also transmitted by Brevipalpus spp. $(19,20,40$ 42). The newly developed RT-PCR assay should be useful to determine whether Brevipalpus spp.-transmitted citrus-leprosislike symptoms producing citrus zonate chlorosis disease $(8,43)$ is caused by CiLV-C2.

Previously, sRDS has been used to identify known and unknown viruses associated with either symptomatic or asymptomatic tissues without any prior knowledge of the pathogen $(12,21,36,54)$. Both the assembly of sRDS reads and reassembly of de novo Sanger sequences indicated that CiLV-C2 was a novel virus in the Colombian leprosis-affected samples. The assembly of 21 - to 22 -nt sRNA sequence reads recovered $\approx 33$ and $\approx 55 \%$ of the total lengths of CiLV-C2 RNA1 and RNA2, respectively, and those regions are significant in terms of the accumulation of sRNAs derived from the CiLV-C2 associated with the leprosislike symptoms. In all, $\approx 1,350$ nt from the $5^{\prime}$ UTR RNA2 and several intergenic regions of RNA1 were not obtained from sRDS, perhaps indicating that those sequences were not targeted by DCL2 endonuclease. Genome sequences of CTV, CEVd, and CDVd sequences were also identified by sRDS from the leprosis samples. The CTV sequence was more prevalent than CiLV-C2 in

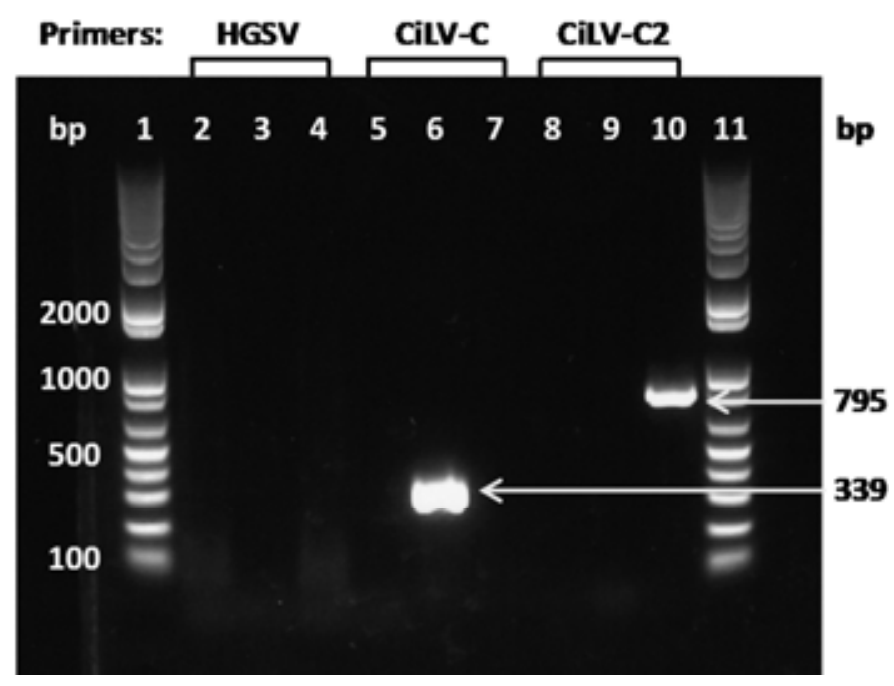

Fig. 8. Specific detection of Citrus leprosis virus cytoplasmic type 2 (CiLV$\mathrm{C} 2$ ) by reverse-transcription polymerase chain reaction using primers specific for the CiLV-C2 coat protein gene. Lanes 1 and 11: 1-kb-plus DNA ladder (Life Technologies, Carlsbad, CA). Source of RNA templates as follows: healthy citrus (lanes 2, 5, and 8); CiLV cytoplasmic type (CiLV-C)-infected citrus (lanes 3, 6, and 9); and CiLV-C2-infected citrus (lanes 4, 7, and 10). Primers used were specific for Hibiscus green spot virus (HGSV) (lanes 2 to 4), CiLV-C (lanes 5 to 7), and CiLV-C2 (lanes 8 to 10).

\section{AA Position : \\ 160 \\ 180 \\ 205 \\ Cilv-C2 \\ : \\ PFGSV \\ LigRSV \\ CiLV-C $\mathrm{C}^{1 \& 2}$ \\ $\mathrm{CiLV}-\mathrm{C}^{3}$ \\ : \\ : \\ : \\ Consensus \\ GNETHRRLGISYEIEHSENLGGGHITFFTLTLLWREAFSLRPSFYKV \\ GNESHRRLGLSYEIEHSENISGGHITTFALTLLWREAFYFQPSNFKV \\ - - - HRRLGIFYQVD-CDDISG-EVTTFAITLLWREAFSFKPSFYQV \\ GSEVHRRLGIQYQVD-CDNISG-RVTTFSITALWREAFSFRPSFYKV GSEVHRRLGIQYQVD-CDNISG-RVTTFSITALWREAFSFRPSFYKV \\ : GSEVHRRLGIQYQVDHCDNISGGRVTTFSITALWREAFSFRPSFYKV}

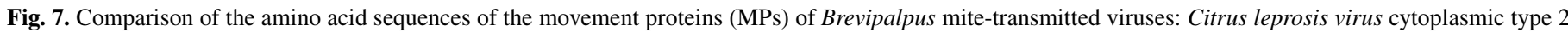

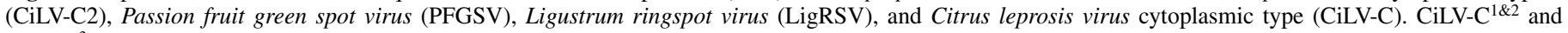

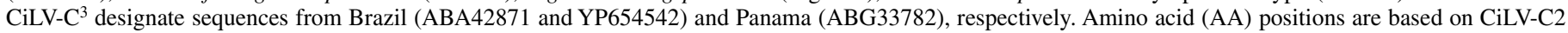

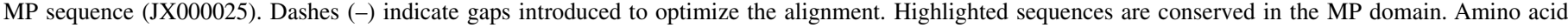

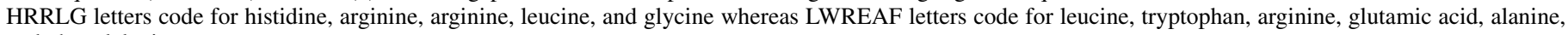
and phenylalanine. 
both libraries, perhaps because CTV infection is systemic rather than local and induces abundant dsRNA (14) that can be processed as substrate for DCL2 to produce siRNA (51).

The nucleotide sequences of RNA1 and RNA2 of CiLV-C2 were determined and comparisons of CiLV-C2 with CiLV-C and HGSV provided important information for taxonomic classification. The organization of the complete CiLV-C2 genome indicated that it is structurally similar to the bipartite CiLV-C genome but not with the tripartite HGSV genome. The genomes of both CiLV$\mathrm{C}$ and CiLV-C2 consist of two replicons with a methylated cap structure at the $5^{\prime}$ and $3^{\prime}$ UTR with a poly(A) tail.

ORF2 of RNA1 of CiLV-C2 encoded a putative CPG (p29) without significant amino acid identity among those of ssRNA positive-sense viruses in the GenBank. The polyclonal antiserum CREC-13 was raised against the p29 of CiLV-C and was used in DAS-ELISA with citrus-leprosis-like samples collected in Colombia. CREC-13 antibodies failed to detect CiLV-C in citrusleprosis-affected samples that were later identified by RT-PCR to be caused by CiLV-C2. This is likely due to the low amino acid identity $(\approx 33 \%)$ between CPGs of CiLV-C and CiLV-C2.

Instead of the four ORFs found in RNA2 of CiLV-C, $(28,37)$, five ORFs were identified in RNA2 of CiLV-C2. The predicted molecular mass of the four shared ORFs was similar. However ORF2 encodes an additional protein of 67 aa (p7), with a putative trans-membrane domain in CiLV-C2. A similar region also was present in the CiLV-C genome spanning $156 \mathrm{nt}$ (491 to $646 \mathrm{nt}$, DQ157465) but these amino acid sequences did not have any trans-membrane domain. The presence of the long intervening UTRs between ORF1 and ORF2 in CiLV-C and CiLV-C2 may prevent the transcription of more than two to three sgRNAs. Many positive-sense RNA viruses express their internal genes via synthesis of $3^{\prime}$-coterminal sgRNAs $(7,32)$. One $3^{\prime}$-coterminal sgRNA from RNA1 and two from RNA2 were found, which suggest that CiLV-C2 could express the putative CP from RNA1 and hypothetical proteins p61 and p24 from the 3' sgRNAs of RNA2. CiLV-C translated four sgRNAs (37).

The MP domain of RNA2 is similar to the 3A/RNA2 superfamily of MPs (Pfam accession PF00803) found in CiLV-C and other ssRNA positive-sense viruses (Fig. 6D). A similar MP domain was not found in the HGSV genome. The complete MP sequences of CiLV-C and CiLV-C2 share 54 to $55 \%$ sequence identity. Partial MP sequences from other Brevipalpus-transmitted viruses such as PFGSV and LigRSV available in the database had a 73 and $39 \%$ identity, respectively, with CiLV-C2. Because the comparison is based on only partial sequence data for the other mite-transmitted viruses, complete MP sequences associated with Brevipalpus mite-transmitted viruses will be necessary to obtain a definitive result.

Phylogenetic analyses of the three conserved domains (MTR, Hel, and RdRp) of RNA1 and the MP domain of RNA2 consistently placed CiLV-C and CiLV-C2 into the same cluster in phylogenetic trees. The conserved MTR and Hel domains of CiLV-C2-RNA1 were distinct and showed more similarity toward members of the genera Cilevirus than Higrevirus (Fig. 6A and B). A phylogeny generated from the RdRp amino acid sequences showed that CiLV-C2 was closely related to other Brevipalpus mite-transmitted viruses such as CiLV-C and LigRSV (Fig. 6C). Phylogenetic analysis with the MP gene sequences from closely related aphid-, fungal-, and mite-transmitted viruses and several viruses with unknown vectors (Fig. 6D) was used to correlate MP sequences with virus-vector relationships. Brevipalpus mitetransmitted viruses such as CiLV-C, CiLV-C2, LigRSV, and PFGSV shared a single clade. Thus, the taxa might have a monophyletic relationship. Alignment of the partial MP sequences revealed two conserved regions among the Brevipalpus mitetransmitted viruses (Fig. 7). These conserved protein sequences might play a role in mite transmission but experimental confirmation is necessary to verify this. All experimental results strongly support the unequivocal classification of CiLV-C2 as a second member of the genus Cilevirus.

CiLV-C was first reported from Colombia in 2004, and it was noted that some of the citrus-leprosis-symptomatic leaves contained CiLV-C particles when viewed in TEM but failed to produce amplicons using CiLV-C-specific RT-PCR (24). We have shown that symptoms and TEM could not be used to distinguish between CiLV-C and CiLV-C2. Based on previous publications $(24,25)$ and the present study, we believe that CiLV-C and CiLVC2 were probably present in Colombia prior to 2004 but the absence of appropriate detection tools prevented the identification of CiLV-C2. Both CiLV-C- and CiLV-C2-specific primers can now be utilized to better understand the distribution and potential impact of these two viruses on Colombian citrus. Unexpectedly, only CiLV-C2 was found in several locations in the states of Meta and Casanare, Colombia. This suggests that previously reported CiLV-C has been reduced or restricted to specific locations in Colombia and may indicate that CiLV-C2 has a selective advantage. Steps should be taken to prevent the dissemination of CiLV$\mathrm{C} 2$ and to determine interactions with CiLV-C.

\section{ACKNOWLEDGMENTS}

Financial support for this research was from the USDA-APHIS-PPQ cooperative agreement 11-8130-1246, and Citrus Research \& Development Foundation grant 405. We thank W. Schneider, USDA Agricultural Research Service, Fort Detrick, MD and S. Gowda, University of Florida/IFAS, CREC, Lake Alfred for providing useful comments and suggestion on the manuscript; and A. S. Guerra for the samples of CiLVC from Panama.

\section{LITERATURE CITED}

1. Al Rwahnih, M. A., Daubert, S., Golino, D., and Rowhani, A. 2009. Deep sequencing analysis of RNAs from a grapevine showing syrah decline symptoms reveals a multiple virus infection that includes a novel virus. Virology 387:395-401.

2. Al Rwahnih, M. A., Daubert, S., Urbez-Torres, J. R., Cordero, F., and Rowhani, A. 2011. Deep sequencing evidence from single grapevine plants reveals a virome dominated by mycoviruses. Arch. Virol. 156:397403.

3. Altschul, S. F., Gish, W., Miller, W., Myers, E. W., and Lipman, D. J. 1990. Basic local alignment search tool. J. Mol. Biol. 215:403-410.

4. Bastianel, M., Freitas-Astúa, J., Nicolini, F., Segatti, N., Novelli, V., Rodrigues, V., Medina, C. L., and Machado, M. A. 2008. Response of mandarin cultivars and hybrids to Citrus leprosis virus. J. Plant Pathol. 90:305-310.

5. Bastianel, M., Noveli, V.M., Kubo, K. S., Kitajima, E. W., Bassanezi, R., Machado, M. A., and Freitas-Astúa, J. 2010. Citrus leprosis: Centennial of an unusual mite-virus pathosystem Plant Dis. 94:284-292.

6. Bitancourt, A. A. 1955. Estudos sobre a leprose dos citros. I-Distribuição geográfica e sintomatologia. Arq. Inst. Biol. 22:161-184.

7. Buck, K. W. 1996. Comparisons of the replication of positive-stranded RNA viruses of plants and animals. Adv. Virus Res. 47:159-251.

8. Chagas, C. M. 2000. Leprosis and zonate chlorosis. Pages 57-58 in: Compendium of Citrus Diseases, Second Edition. L. W. Timmer, S. M. Garnsey, and J. H. Graham, eds. American Phytopathological Society Press, St. Paul, MN.

9. Childers, C. C., Rodrigues, J. C. V., Derrick, K. S., Achor, D. S., French, J. C., Welbourn, W. C., Ochoa, R., and Kitajima, E. W. 2003. Citrus leprosis and its status in Florida and Texas: Past and present. Exp. Appl. Acarol. 30:181-202.

10. Choudhary, N., Roy, A., Leon, G.A., Levy, L., and Brlansky, R. H. 2011. Detection of Citrus leprosis virus cytoplasmic type utilizing the polyclonal antibodies specific to the movement and coat proteins. (Abstr.) Phytopathology 101:S36.

11. Clark, M. F., Lister, R. M., and Bar-Joseph, M. 1986. ELISA techniques. Methods Enzymol. 118:742-766.

12. Coetzee, B., Freeborough, M. J., Maree, H. J., Celton, J. M., Rees, D. J. G., and Burger, J. T. 2010. Deep sequencing analysis of viruses infecting grapevines: Virome of a vineyard. Virology 400:157-163.

13. Colariccio, A., Lovisolo, O., Chagas, C. M., Galletti, S. R., Rossetti, V., and Kitajima, E. W. 1995. Mechanical transmission and ultrastructural aspects of citrus leprosis disease. Fitopatol. Bras. 20:208-213.

14. Dodds, J. A., and Bar-Joseph, M. 1983. Double-stranded RNA from 
plants infected with closteroviruses. Phytopathology 73:419-423.

15. Iracheta-Cardenas, M. M., Metheney, P., Polek, M. L., Manjunath, K. L., Lee, R. F., and Rocha-Pena, M. A. 2009. Serological detection of Citrus tristeza virus with antibodies developed to the recombinant coat protein. Plant Dis. 93:11-16.

16. Hartung, J. S., Paul, C., Achor, D., and Brlansky, R. H. 2010. Colonization of dodder, Cuscuta indecora, by 'Candidatus Liberibacter asiaticus' and ' $\mathrm{Ca}$. L. americanus'. Phytopathology 100:756-762.

17. Hull, R. 2009. Replication of plus sense single stranded RNA viruses. Pages 140-151 in: Comparative Plant Virology, section II, chapter 8. Elsevier Academic Press, London.

18. Kashif, M., Pietilä, S., Artola, K., Jones, R., Tugume, A. K., Mäkinen, V., and Valkonen, J. 2012. Detection of viruses in sweet potatoes from Honduras and Guatemala augmented by deep-sequencing of small-RNAs. Plant Dis. 96:1430-1437.

19. Kitajima, E. W., Chagas, C. M., and Rodrigues, J. C. V. 2003. Brevipalpus-transmitted plant virus and virus-like diseases: Cytopathology and some recent cases. Exp. Appl. Acarol. 30:135-160.

20. Kitajima, E. W., Rodrigues, J. C. V., and Freitas-Astua, J. 2010. An annotated list of ornamentals naturally found infected by Brevipalpus mite-transmitted viruses. Sci. Agric. 67:348-371.

21. Kreuze, J. F., Perez, A., Untiveros, M., Quispe, D., Fuentes, S., Barker, I., and Simon, R. 2009. Complete viral genome sequence and discovery of novel viruses by deep sequencing of small RNAs: A generic method for diagnosis, discovery and sequencing of viruses. Virology 388:1-7.

22. Langmead, B., Trapnell, C., Pop, M., and Salzberg, S. L. 2009. Ultrafast and memory-efficient alignment of short DNA sequences to the human genome. Genome Biol. 10:R25. Online publication. doi:10.1186/gb-2009$10-3-r 25$

23. León, G. A., Becerra, C. H., Freitas-Astúa, J., Salaroli, R. B., and Kitajima, E. W. 2008. Natural infection of Swinglea glutinosa by the cytoplasmic type (CiLV-C) in Colombia. Plant Dis. 92:364-1364.

24. León, G. A., Freitas-Astúa, J., Kitajima, E. W., and Meza, N. C. 2006. Detection of the cytoplasmic Citrus leprosis virus in the eastern plains of Colombia. Rev. Corpoica Cienc. Tecnol. Agropec. 7:67-72.

25. León, G. A., Realpe, C. E., Garzon, P. A., Rodriguez, J. A., Moreno, M. G., Childers, C. C., Achor, D., Freitas-Astúa, J., Antonioli-Luizon, R., Salaroli, S. B., Cobo, N. C. M., and Kitajima, E. W. 2006. Occurrence of Citrus leprosis virus in Llanos Orientales, Colombia. Plant Dis. 90:682.

26. Llave, C. 2010. Virus-derived small interfering RNAs at the core of plantvirus interactions. Trends Plant Sci. 15:701-707.

27. Locali, E. C., Freitas-Astúa, J., Souza, A. A., Takita, M. A. J., Antonioli, R., Kitajima, E. W., and Machado, M. A. 2003. Development of molecular tool for the diagnosis of leprosis a major threat to citrus production in the Americas. Plant Dis. 87:1317-1321.

28. Locali-Fabris, E. C., Freitas-Astu, J., Souza, A. A., Takita, M. A., AstuaMonge, G., Antonioli-Luizon, R., Rodrigues, V., Targon M. L. P. N., and Machado, M. A. 2006. Complete nucleotide sequence, genomic organization and phylogenetic analysis of Citrus leprosis virus cytoplasmic type. J. Gen. Virol. 87:2721-2729.

29. Loconsole, G., Onelge, N., Potere, O., Giampetruzzi, A., Bozan, O., Satar, S., De Stradis, A., Savino, V. N., Yokomi, R. K., and Saponari, M. 2012. Identification and characterization of Citrus yellow vein clearing virus, a putative new member of the genus Mandarivirus. Phytopathology 102:1168-1175.

30. Loconsole, G., Saldarelli, P., Doddapaneni, H., Savino, V., Martelli, G. P., and Saponari, M. 2012. Identification of a single-stranded DNA virus associated with citrus chlorotic dwarf disease, a new member in the family Geminiviridae. Virology 432:162-172.

31. Melzer, M. J., Sether, D. M., Borth, W. B., and Hu, J. S. 2012. Characterization of a virus infecting Citrus volkameriana with citrus leprosislike symptoms. Phytopathology 102:122-127.

32. Miller, W. A., and Koev, G. 2000. Synthesis of subgenomic RNAs by positive-strand RNA viruses. Virology 273:1-8.

33. Nicholas, K. B., and Nicholas, H. B., Jr. 1997. GeneDoc: A tool for editing and annotating multiple sequence alignments. www.psc.edu/ biomed/genedoc

34. Nunes, M. A., Oliveira, C. A. L., Oliveira, M. L., Kitajima, E. W. Hilf, M. E., Gottwald, T., and Freitas-Astúa, J. 2012. Transmission of Citrus leprosis virus $C$ by Brevipalpus phoenicis 1 (Geijskes) to alternative host plants found in citrus orchards. Plant Dis. 96:968-972.

35. Pallett, D. W., Ho, T., Cooper, I., and Wang, H. 2010. Detection of Cereal yellow dwarf virus using small interfering RNAs and enhanced infection rate with Cocksfoot streak virus in wild cocksfoot grass (Dactylis glomerata). J. Virol. Methods 168:223-227.

36. Pantaleo, V., Saldarelli P., Miozzi, L., Giampetruzzi, A., Gisel, A., Moxon, S., Dalmay, T., Bisztray, G., and Burgyan, J. 2010. Deep sequencing analysis of viral short RNAs from an infected Pinot Noir grapevine. Virology 408:49-56.

37. Pascon, R. C., Kitajima, J. P., Breton, M. C., Assumpcao, L., Greggio, C., Zanca, A. S., Okura, V. K., Alegria, M. C., Camargo, M. E., Silva, G. G. C., Cardozo, J. C., Vallim, M. A., Franco, S. F., Silva, V. H., Junior, H. J., Oliveira, F., Giachetto, P. F., Ferrari, F., Aguilar-Vildoso, C. I., Franchiscini, F. J. B., Silva, J. M. F., Arruda, P., Ferro, J. A., Reinach, F., and Silva, A. C. R. 2006. The complete nucleotide sequence and genomic organization of Citrus leprosis associated virus, cytoplasmatic type (CiLVC). Virus Genes 32:289-298.

38. Quan, P., Briese, T., Palacios, G., and Lipkin, W. I. 2008. Rapid sequencebased diagnosis of viral infection. Antiviral Res. 79:1-5.

39. Reynolds, E. S. 1963. The use of lead citrate at high $\mathrm{pH}$ as an electron dense stain for electron microscopy. J. Cell Biol. 17:08-212.

40. Rodrigues, J. C. V., Kitajima, E. W., Childers, C. C., and Chagas, C. M. 2003. Citrus leprosis virus vectored by Brevipalpus phoenicis (Acari: Tenuipalpidae) on citrus in Brazil. Exp. Appl. Acarol. 30:161-179.

41. Rodrigues, J. C. V., Machado, M. A., Kitajima, E. W., and Müller, G. W. 2000. Transmission of Citrus leprosis virus by Brevipalpus phoenicis (Acari: Tenuipalpidae). Pages 174-178 in: Proc. 14th Conf. Int. Org. Citrus Virol. J. V. da Graca, R. F. Lee, and R. K. Yokomi, eds. IOCV, Riverside, CA.

42. Rodrigues, J. C. V., Nogueira, N. L., and Freitas, D. S. 1995. Ringspot on Ligistrum lucidum Aiton, a new disease transmitted by Brevipalpus phoenicis G. (Acari: Tenupalpidae), in Brazil. Fitopatol. Bras. 20:292.

43. Rossetti, V., Lasca, C. C., and Negretti, S. 1969. New developments regarding leprosis and zonate chlorosis of citrus. Pages 1453-1456 in: Proc. 1st Int. Citrus Symp. H. D. Chapman, ed. University of California, Riverside.

44. Roy, A., and Brlansky, R. H. 2010. Genome analysis of an orange stem pitting Citrus tristeza virus isolate reveals a novel recombinant genotype. Virus Res. 151:118-130.

45. Sambrook, J., Fritsch, E. M., and Maniatis, T. 1989. Molecular Cloning: A Laboratory Manual, 2nd ed. Cold Spring Harbor Laboratory Press, Cold Spring Harbor, NY.

46. Schultz, J., Milpetz, F., Bork, P., and Ponting, C. 1998. SMART, a simple modular architecture research tool: Identification of signaling domains. Proc. Natl. Acad. Sci. USA 95:5857-5864.

47. Schulz, M. H., Zerbino, D. R., Vingron, M., and Birney, E. 2012. Oases: robust de novo RNA-seq assembly across the dynamic range of expression levels. Bioinf. Adv. Access 28:1-7.

48. Spurr, A. R. 1969. A low-viscosity epoxy resin embedding medium for electron microscopy. J. Ultrastruct. Res. 26:31-43.

49. Tamura, K., Peterson, D., Peterson, N., Stecher, G., Nei, M., and Kumar, S. 2011. MEGA5: Molecular evolutionary genetics analysis using maximum likelihood, evolutionary distance, and maximum parsimony methods. Mol. Biol. Evol. 28:2731-2739.

50. Thompson, J. D., Gibson, T. J., Plewniak, F., Jeanmougin, F., and Higgins, D. G. 1997. The Clustal X windows interface: Flexible strategies for multiple sequence alignment aided by quality analysis tools. Nucleic Acids Res. 24:876-4882.

51. Vazquez, F., Legrand, S., and Windels, D. 2010. The biosynthetic pathways and biological scopes of plant small RNAs. Trends Plant Sci. 15:37-345.

52. Wu, Q., Luo, Y., Lu, R., Lau, N., Lai, E. C. Li, W., and Ding, S. 2010. Virus discovery by deep sequencing and assembly of virus-derived small silencing RNAs. Proc. Natl. Acad. Sci. USA 107:1606-1611.

53. Zerbino, D.R., and Birney, E. 2008. Velvet: Algorithms for de novo short read assembly using de Bruijn graphs. Genome Res. 18:821-829.

54. Zhang, Y., Singh, K., Kaur, R., and Qiu, W. 2011. Association of a novel DNA virus with the grapevine vein-clearing and vine decline syndrome. Phytopathology 101:1081-1090. 